\title{
ADVANCED GASIFIER PILOT PLANT CONCEPT DEFINITION
}

\section{TOPICAL REPORT}

\author{
Reporting Period \\ Start Date: $\quad$ October 1, 2004 \\ End Date: $\quad$ August 31, 2005 \\ Steve Fusselman \\ Principal Authors

$\begin{array}{ll}\text { Alan Darby } & \text { Program Manager } \\ \text { Fred Widman } & \text { Project Engineer }\end{array}$ \\ Task Lead \\ Program Manager \\ Project Engineer
}

September 2006

\section{DOE Award Number \\ DE-FC26-04NT42237 \\ Task 3}

Pratt \& Whitney Rocketdyne, Inc.

6633 Canoga Avenue

P. O. Box 7922

Canoga Park, CA 91309-7922 


\section{DISCLAIMER}

This report was prepared as an account of work sponsored by an agency of the United States Government. Neither the United States Government nor any agency thereof, nor any of their employees, makes any warranty, express or implied, or assumes any legal liability or responsibility for the accuracy, completeness, or usefulness of any information, apparatus, product, or process disclosed, or represents that its use would not infringe privately owned rights. Reference herein to any specific commercial product, process, or service by trade name, trademark, manufacturer, or otherwise does not necessarily constitute or imply its endorsement, recommendation, or favoring by the United States Government or any agency thereof. The views and opinions of authors expressed herein do not necessarily state or reflect those of the United States Government or any agency thereof. 


\section{ABSTRACT}

This report presents results from definition of a preferred commercial-scale advanced gasifier configuration and concept definition for a gasification pilot plant incorporating those preferred technologies. The preferred commercial gasifier configuration was established based on Cost Of Electricity estimates for an IGCC. Based on the gasifier configuration trade study results, a compact plug flow gasifier, with a dry solids pump, rapid-mix injector, CMC liner insert and partial quench system was selected as the preferred configuration. Preliminary systems analysis results indicate that this configuration could provide cost of product savings for electricity and hydrogen ranging from 15\%-20\% relative to existing gasifier technologies. This cost of product improvement draws upon the efficiency of the dry feed, rapid mix injector technology, low capital cost compact gasifier, and $>99 \%$ gasifier availability due to long life injector and gasifier liner, with short replacement time.

A pilot plant concept incorporating the technologies associated with the preferred configuration was defined, along with cost and schedule estimates for design, installation, and test operations. It was estimated that a 16,300 kg/day (18 TPD) pilot plant gasifier incorporating the advanced gasification technology and demonstrating 1,000 hours of hot-fire operation could be accomplished over a period of 33 months with a budget of $\$ 25.6 \mathrm{M}$. 


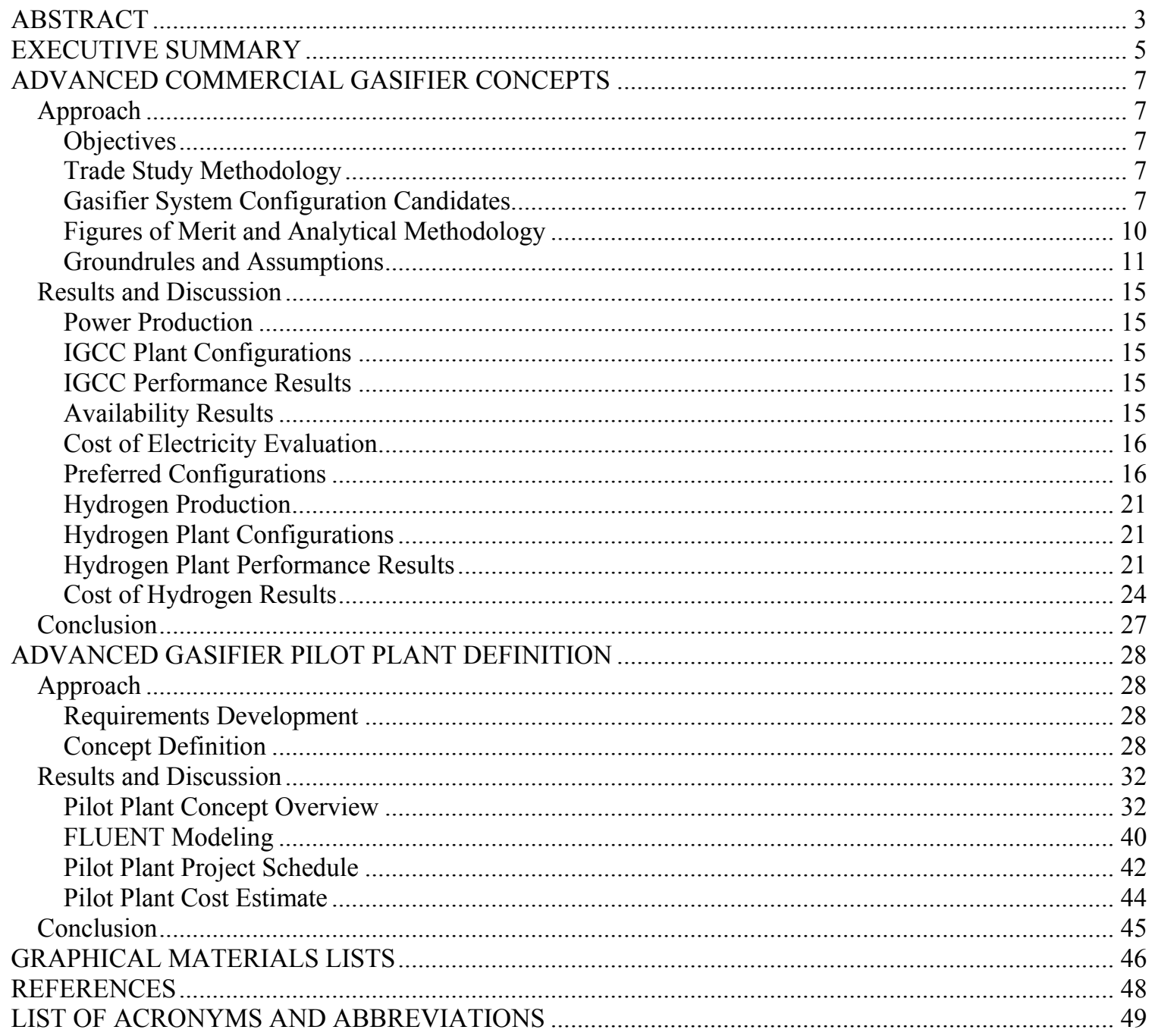




\section{EXECUTIVE SUMMARY}

This topical report presents results from Task 3, "Pilot Plant Definition and Planning", for the Advanced Gasification Systems Development program. The objective of this task was to perform conceptual design and hardware definition of an 18 tpd pilot-scale advanced gasifier and dry coal feed system, with the design based on similar geometry and performance of the envisioned commercial scale unit (approximately 3,000 tpd), such that the performance of the pilot plant is traceable to the commercial system. Detailed engineering planning was performed to develop a cost estimate for the detailed design, fabrication, construction and long-duration test of the 18 tpd pilot plant.

The effort was divided into two sub-tasks: definition of advanced commercial gasifier concepts, and advanced gasifier pilot plant definition. The purpose of the commercial gasifier concepts task was to identify a preferred gasifier configuration to serve as the basis for the pilot plant. The purpose of the pilot plant definition task was to define the pilot plant effort in sufficient detail to develop schedule and cost estimates.

The approach for the advanced commercial gasifier concepts employed a systematic trade study methodology compliant with DOE energy system study quality guidelines to identify and evaluate a suite of potential advanced gasifier configurations. Feed system, gasifier liner, and quench system configurations were evaluated for system-level impacts on plant efficiency, availability, capital cost, and cost of product.

A carbon dioxide $\left(\mathrm{CO}_{2}\right)$ slurry based system and a dry solids pump were evaluated for conveying coal into a high pressure hopper for dry, dense phase transport. A dry pumptype approach was found to provide $\sim 5 \%$ lower capital cost per $\mathrm{kW}_{\mathrm{e}}$ than the $\mathrm{CO}_{2}$ slurry approach, with no significant impact estimated for plant availability and efficiency.

Two CMC liner configurations were evaluated: an integrally cooled CMC liner with internal steam coolant passages and a CMC insert cooled by a water-cooled metal jacket surrounding the insert. The simpler CMC insert approach provided capital cost savings that more than offset a minor efficiency penalty, resulting in lower Cost of Electricity (COE).

Three quench configurations were evaluated: a deluge quench that cools the syngas product down to the saturation temperature of the water bath; a partial quench that cools the syngas to a temperature amenable to dry particulate removal via water injection; and a heat exchanger (HEX) quench that removes sensible heat via heat transfer through a $\mathrm{CMC}$ heat exchanger to raise high pressure steam. The partial quench and deluge quench resulted in the same COE. The partial quench approach was chosen due to expectations of greater operational simplicity over time, and ease of handling solid waste products. The HEX quench approach, if implemented without adverse impact to availability and capital cost, would provide substantial COE reduction, but should be deferred until CMC 
compatibility within the gasifier environment is more fully established, and the gasifier effluent environment is better understood.

The preferred configuration consisting of a dry pump-based feed system, CMC insert lined gasifier, and partial quench system was estimated to provide gasifier availability $>99 \%$ due to long life (1 year minimum and 3 year design target for the injector, and 3 years minimum and 10 years design target for the CMC insert) and short Mean Time To Repair (6 hours for the injector, 24 hours for the liner). The overall system impact of gasifier performance, availability and capital cost improvements have the potential to decrease plant capital cost by $15 \%$ and to reduce cost of product by $15-20 \%$ for electricity generation, as well as hydrogen production.

The approach for pilot plant definition was to define requirements traceable to the preferred commercial gasifier configuration, followed by a systematic concept definition process to establish an integrated technical baseline for the pilot plant to serve as the basis for cost and schedule estimates. This included development of mass and energy balances, Process Flow Diagrams, Piping and Instrumentation Diagrams, and layouts for the overall plant, as well as more detailed definition of the gasifier design and fabrication approach. Materials, thermal, mechanical, and stress evaluations were performed on gasifier components to assure that a feasible design concept had been selected. Engineering planning of design, fabrication, construction and test activities were performed to develop estimated schedule and cost for the overall pilot plant project.

A pilot plant project demonstrating the technologies applied to the preferred commercial gasifier configuration was estimated to require a 33 month schedule and $\$ 25.6 \mathrm{M}$ funding, providing 1,000 hours cumulative hot-fire testing on bituminous and sub-bituminous feedstock. 


\section{ADVANCED COMMERCIAL GASIFIER CONCEPTS}

\section{Approach}

\section{Objectives}

The objectives of the Advanced Commercial Gasifier Concepts task were:

(1) Define requirements for an advanced commercial gasifier with cooled liner

(2) Establish a preferred commercial advanced gasifier system configuration to serve as the reference point for advanced gasifier pilot plant concept definition.

Advanced gasifier requirements were developed based on DOE goals and commercial market needs. The preferred commercial advanced gasifier system configuration was determined by trade studies evaluating a range of potential configurations relative to predicted commercial performance.

\section{Trade Study Methodology}

A systematic trade study methodology was employed to identify the preferred commercial gasifier configuration. It consisted of the following steps:

- Identify gasifier configuration candidates

- Define trade study figures of merit against which candidate configurations are evaluated

- Establish analytical methodology for each figure of merit

- Stipulate groundrules and assumptions constraining analytical methodology

- Perform the analysis and evaluate results.

\section{Gasifier System Configuration Candidates}

The gasifier system consists of a feed system, the gasifier, and a quench system.

Two feed system options were evaluated: a $\mathrm{CO}_{2}$ slurry-based system, and a dry pump system. Both systems accept dry pulverized coal at atmospheric pressure, and transport the coal into the gasifier at high pressure using a small quantity, typically $0.03 \mathrm{Nm}^{3}$ of transport gas per $\mathrm{kg}$ coal $\left(\sim 0.5 \mathrm{scf}\right.$ per $\left.\mathrm{lb}_{\mathrm{m}}\right)$. These dry feed systems enable high Cold Gas Efficiency (CGE) by eliminating the introduction of large quantities of water (typically at $\sim 0.5 \mathrm{~kg}$ per $\mathrm{kg}$ of coal) into the gasifier associated with water-based slurry feed systems.

The gasifier consists of the rapid mix injector and the gasification chamber. The injector was assumed to have 36 impinging injector elements. Two gasification chamber options were considered: a channel-wall, integrally cooled ceramic matrix composite (CMC) liner with steam cooled passages, supported by a surrounding metal support structure, and a CMC insert cooled by a metal wall support structure with channel wall coolant passages.

The quench system accepts the raw syngas from the gasifier at slagging temperatures, reduces the temperature of the syngas by either heat transfer or addition of water, and removes particulates from the syngas. The quench system product is a particulate-free syngas at a temperature suitable for downstream processing $\left(<425^{\circ} \mathrm{C}\right)$. Three quench configurations were evaluated:

- Deluge quench, similar to the existing Texaco gasifier with quench, resulting in a saturated syngas product and a wet ash product.

- Partial quench, where water is injected into the raw syngas to reduce the temperature to a range suitable for particulate removal devices $\left(<425^{\circ} \mathrm{C}\right)$, yielding syngas $>30^{\circ} \mathrm{C}$ above saturation and a dry ash product. 
- Heat Exchanger (HEX) quench, where sensible heat is extracted from the syngas in a compact $\mathrm{CMC}$ heat exchanger to raise high pressure steam at $\sim 560^{\circ} \mathrm{C}\left(1,050^{\circ} \mathrm{F}\right)$ and the syngas is cooled to a range suitable for particulate removal devices, yielding dry syngas and a dry ash product. Existing heat exchanger technology was not evaluated as part of the trade space, as recent NETL studies indicate that the high capital expense outweighs the efficiency improvement, causing a net increase in cost of electricity when a heat exchanger is included.

The trade tree for gasifier configurations is shown in Figure 1 below. Basic configurations for the deluge quench, partial quench, and HEX quench options are shown in Figures 2, 3 and 4, respectively.

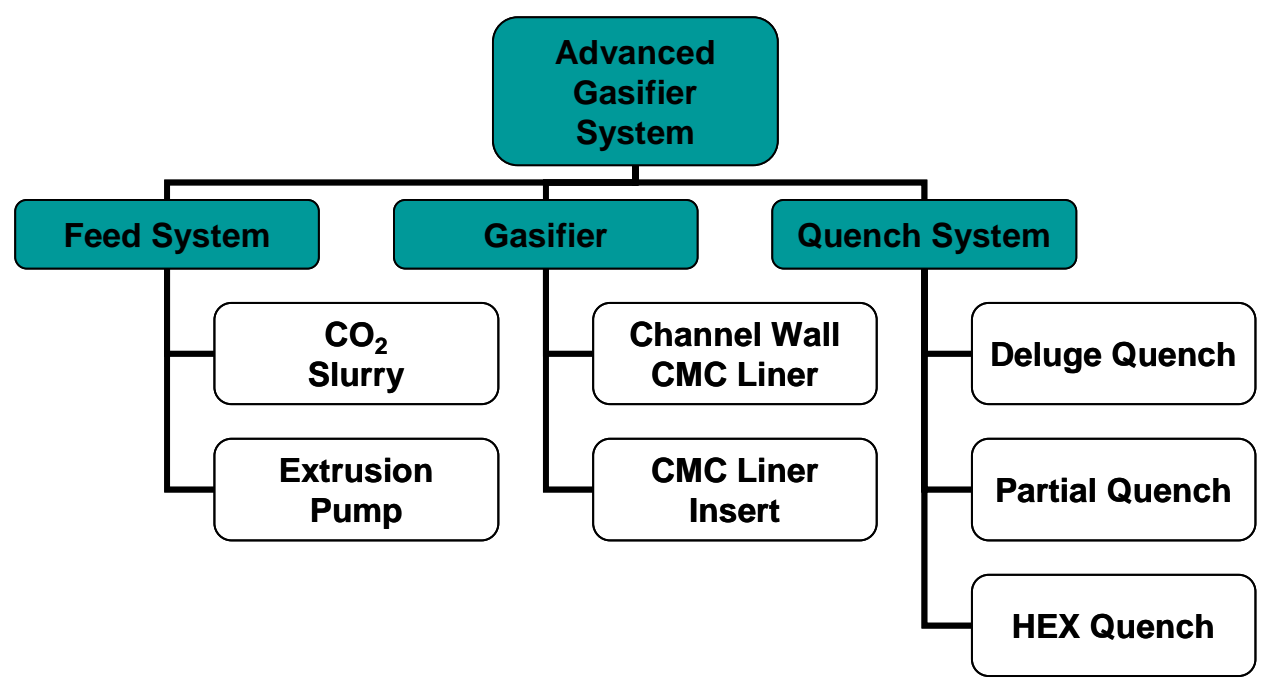

Figure 1. Gasifier configuration trade tree for commercial concept definition. 


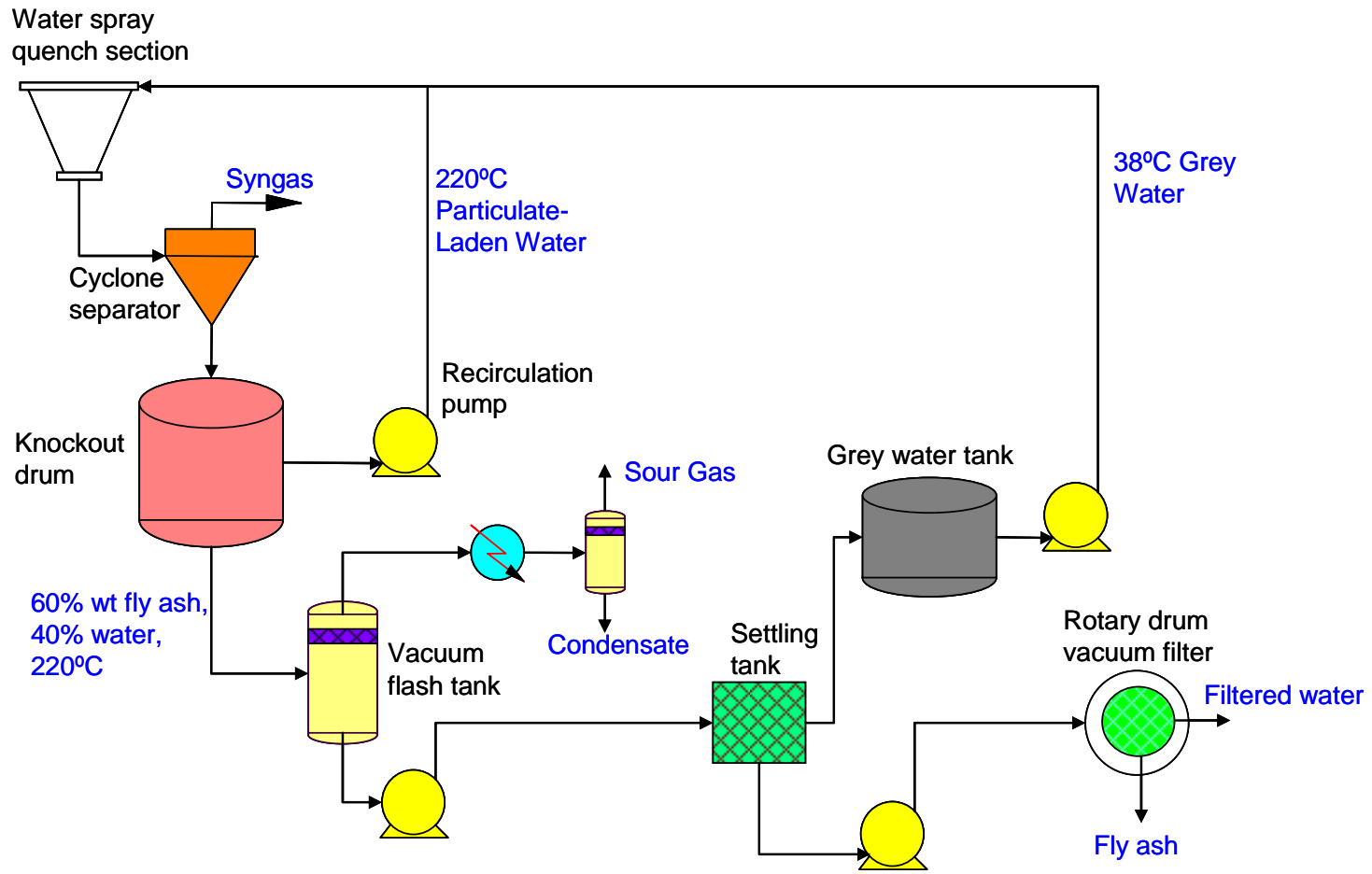

Figure 2. Deluge quench process schematic.

Water spray quench section

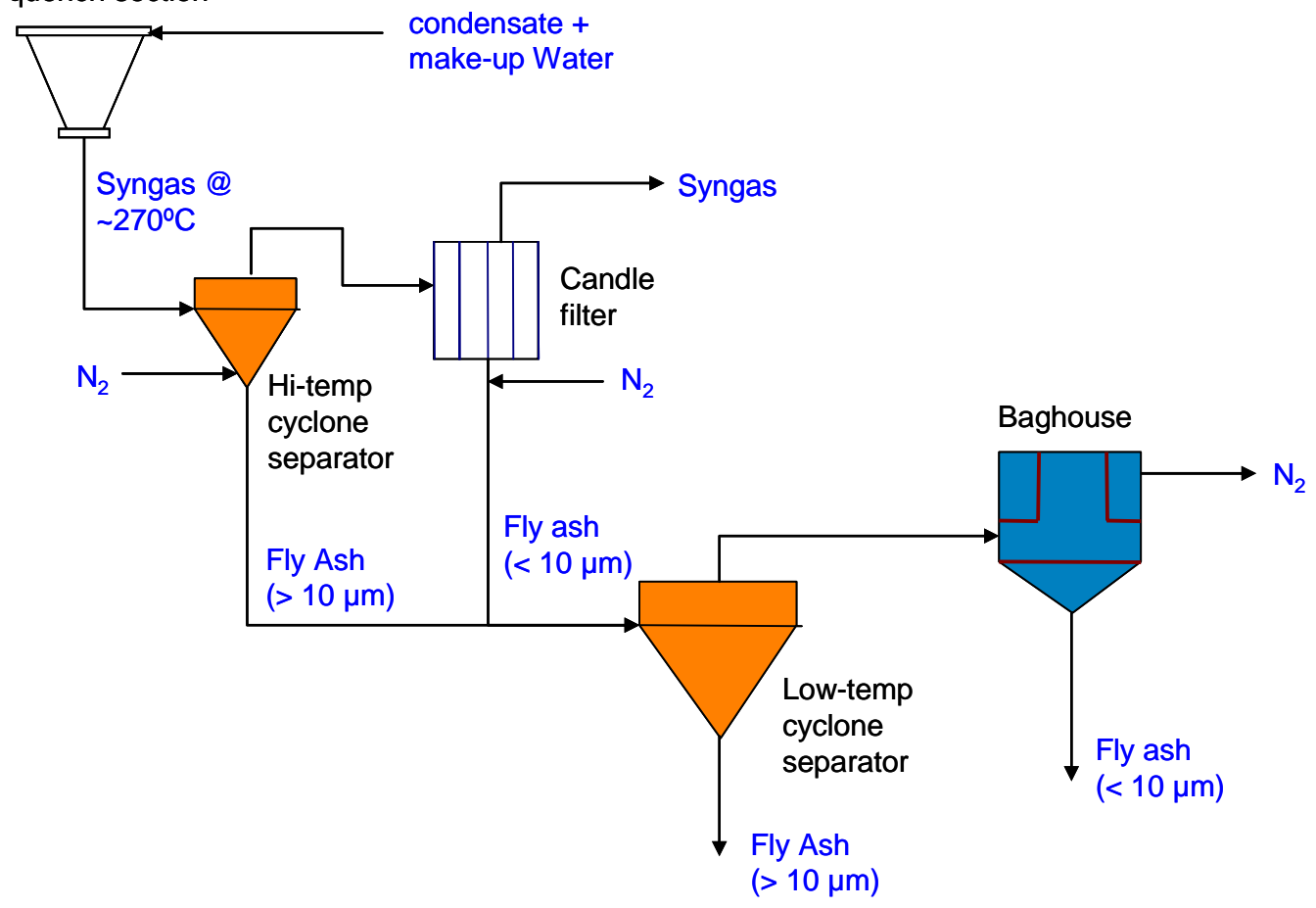

Figure 3. Partial quench process schematic. 


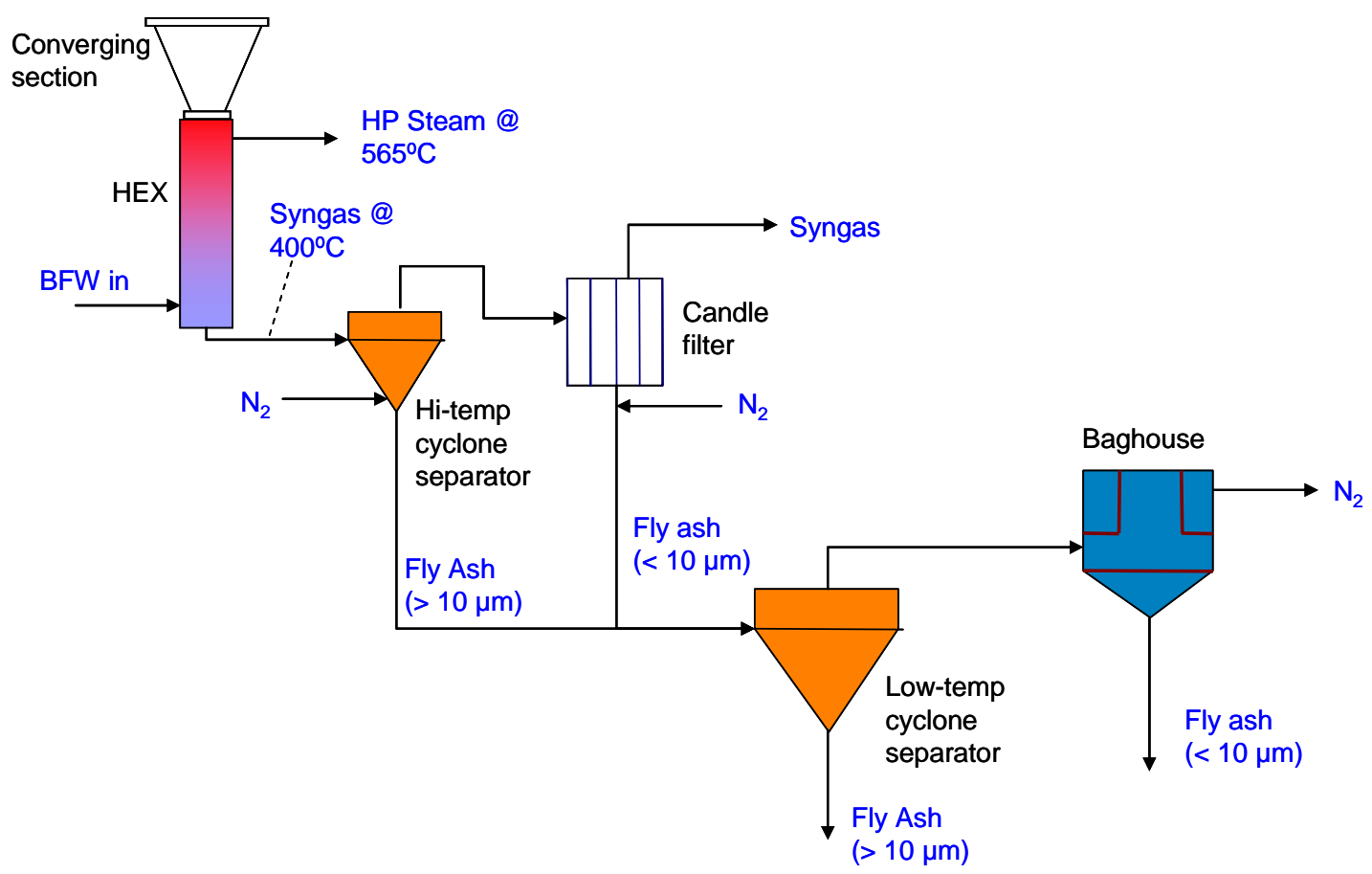

Figure 4. HEX quench process schematic.

\section{Figures of Merit and Analytical Methodology}

Gasifier system configurations were evaluated for impacts on plant efficiency (electric power efficiency for IGCC, $\mathrm{H}_{2}$ thermal efficiency for $\mathrm{H}_{2}$ plants), plant availability, plant capital cost, and cost of product (cost of electricity for IGCC, cost per $\mathrm{GJ}_{2}$ for $\mathrm{H}_{2}$ plants).

Analytical methodology to evaluate configurations relative to these figures of merits were structured to comply with the "Quality Guidelines for Energy System Studies", issued February 24, 2004 by the Department of Energy Office of Systems and Policy Support.

Plant efficiency estimates were developed from modeling of the entire IGCC or $\mathrm{H}_{2}$ production plant using ChemCAD 5.3.0. A Texaco quench gasifier, with performance as indicated in detailed stream data provided by DOE-NETL from "Texaco Gasifier IGCC Base Cases", PED-IGCC-98-001, June 2000, was used as the basis of comparison. The entire "Texaco IGCC - Case 1" plant was replicated in ChemCAD based on the detailed stream data, yielding implicit assumptions regarding process parameters such as turbine efficiencies, compressor efficiencies, heat exchanger approach temperatures, separation factors for sulfur removal steps, and HRSG composite heat curve minimum $\Delta \mathrm{T}$. These assumptions were then applied as constraints to advanced gasifier configuration cases to ensure that comparative data were not biased by assumptions not related to the gasifier system. All of these assumptions are described in the groundrules and assumptions section below.

Availability estimates were developed using a comparative design assessment methodology for the gasifier feed and quench systems, and by estimating component life and Mean Time To Repair (MTTR) for the gasifier. Historical data from the Tampa Electric Polk Power Station IGCC demonstrator ("Tampa Electric Polk Power Station Integrated Gasification Combined Cycle Project - Final Technical Report", August 2002) and the Wabash River IGCC demonstrator ("Wabash River Coal Gasification Repowering Project Final Technical Report", August 2000) were used as the basis for comparison. Life estimates for gasifier components (injector, liner and structural shell) were based on engineering assessments of feasible component life within anticipated operating environments. Mean Time To Repair was estimated by assessing gasifier layout/elevations for component accessibility and a task buildup evaluation for all steps required between safe gasifier shutdown and gasifier start-up. The task buildup evaluation consists of 
listing each step in the component replacement process (i.e., feed line connection removal, flange disassembly, leak checks) and estimating the duration required to perform each step. PWR personnel experienced in the design and operation of large scale, high temperature test facilities performed the task buildup evaluation.

Advanced gasifier system feed, gasifier and quench equipment costs were based on "bottoms-up" estimates. These estimates had as their basis discrete estimates for the major components, with typical multipliers for IA\&T (integration, assembly and test), fee, ROM/contingency factor, and installation factor to arrive at an installed cost basis. Other plant equipment capital costs were factored (based on equipment capacity) from literature data as follows:

- Texaco feed/gasifier/quench, other IGCC plant from PED-IGCC-98-001, June 2000.

- For $\mathrm{H}_{2}$ cases: Selexol process, $\mathrm{CO} 2$ compression/drying, and SRU from "Advanced Fossil Power Systems Comparison Study”, December 2002 (pg. B-43).

- For $\mathrm{H}_{2}$ cases: Shift reaction and PSA from "Co-production of Hydrogen, Electricity and $\mathrm{CO}_{2}$ from Coal with Commercially Ready Technology - Part B: Economic Analysis”, T. Kreutz et al., Int. J. Hydrogen Energy, 2004.

Overall plant costs were estimated using the same cost model employed by NETL in PED-IGCC-98-001, with adjustments as appropriate for flow rates, utilities, and consumables. Costs were escalated by $3 \% /$ year from reference year \$'s to CY 2004 \$'s.

Cost of product (electricity or hydrogen) estimates were developed using the same cost model employed by NETL in PED-IGCC-98-001, with modifications as appropriate for process plant costs, consumables, and capacity factor (availability). Cost of product is reported in $10^{\text {th }}$-year levelized CY 2004 \$'s. This represents the overarching figure of merit, reflecting the systems-level impact of plant efficiency, availability and capital cost impacts.

\section{Groundrules and Assumptions}

The following constraints were applied to electricity (IGCC) and $\mathrm{H}_{2}$ production cases to enforce consistency/avoid bias in case comparisons. While individual groundrules/assumptions may require further refinement or correction for an absolute analysis, we believe that, when consistently applied across a given class of cases, they are adequate for the comparative analysis presented here.

Groundrules and assumptions common to both IGCC and $\mathrm{H}_{2}$ production cases are listed in Table I. Those specific to IGCC cases are listed in Table II. Those specific to Hydrogen plant cases are listed in Table III.

Illinois \#6 coal as defined in PED-IGCC-98-001 was used as the bituminous coal. Lignite and subbituminous coal compositions given in "Quality Guidelines for Energy System Studies" were used, with the fuels assumed dried to $15 \%$ moisture by weight prior to use in the gasifier. Petcoke composition corresponded to the Chalmette Refinery petcoke referenced in Table 5-3 of the Tampa Electric Polk Power Station IGCC Project Final Technical Report. 
Table I. Groundrules and Assumptions Common to IGCC and $\mathrm{H}_{2}$ Production Cases.

\section{Fuel Pulverization and Drying}

(1) Nominal power consumption of $0.018 \mathrm{~kW}-\mathrm{hr} / \mathrm{kg}$ dry solid coal for pulverization, $0.115 \mathrm{~kW}$-hr/ $\mathrm{kg}$ for dry petcoke.

(2) Coal pulverized to extent that $70 \mathrm{wt} \%$ passes thru 200 mesh screen

(3) Dryer requires $\mathrm{N}_{2}$ at $163^{\circ} \mathrm{C}\left(325^{\circ} \mathrm{F}\right)$. Heat extracted from SCOT vent gas combusted for CO2, other waste heat, or LP steam.

(4) Inlet fuel moisture content per spec. Dried to $2 \%$ moisture (weight basis) for coal and petcoke, $15 \%$ for sub-bituminous, lignite

\section{Fuel Carbon Dioxide Slurry System}

(1) Consumes $0.015 \mathrm{~kW}-\mathrm{hr} / \mathrm{kg}$ of dried fuel

(2) $\mathrm{CO}_{2}$ inlet conditions: $21^{\circ} \mathrm{C}$ and $6.9 \mathrm{MPa}\left(70^{\circ} \mathrm{F}\right.$ and $\left.1000 \mathrm{psia}\right)$

(3) Slurry outlet conditions: $90^{\circ} \mathrm{C}$ and $8.3 \mathrm{MPa}\left(195^{\circ} \mathrm{F}\right.$ and $\left.1200 \mathrm{psia}\right)$.

(4) Slurry requires some low-grade heat @ $163^{\circ} \mathrm{C}\left(325^{\circ} \mathrm{F}\right)$ to achieve $90^{\circ} \mathrm{C}\left(195^{\circ} \mathrm{F}\right)$ outlet temp. Not modeled in PFD.

\section{Fuel Dry Pump System}

(1) Consumes $0.98 \mathrm{MW}$ for $113,400 \mathrm{~kg} / \mathrm{hr}(3,000 \mathrm{TPD})$ dry feed

(2) Requires $0.031 \mathrm{Nm}^{3}$ transport gas per $\mathrm{kg}\left(0.5 \mathrm{scf}\right.$ per $\left.\mathrm{lb}_{\mathrm{m}}\right)$ of dry feed (comparable to $\mathrm{CO}_{2}$ feed in $\mathrm{CO}_{2}$ slurry system)

\section{Gasifier}

(1) Adjust product composition to match output from PWR gasifier analysis with equivalent Cold Gas Efficiency.

(2) Accept temperature of output as determined by ChemCAD from given inputs.

\section{Quench}

(1) HEX quench accepts gasifier effluent at outlet conditions (no pre-cooling with partial quench).

(2) Partial quench cools syngas to temp $\sim 30^{\circ} \mathrm{C}\left(50^{\circ} \mathrm{F}\right)$ above dew point prior to candle filter.

(3) Candle filter pressure drop $=0.07 \mathrm{MPa}$ (10 psia). Assume minimal blow-down loss.

(4) Deluge quench effluent has minimum 33\% water in ash.

\section{Heat Exchangers}

(1) $28^{\circ} \mathrm{C}\left(50^{\circ} \mathrm{F}\right)$ minimum delta $\mathrm{T}$ across composite heat curve for HRSG, syngas cooling sections.

(2) $11^{\circ} \mathrm{C}\left(20^{\circ} \mathrm{F}\right)$ minimum delta $\mathrm{T}$ across heat curve for all other HEX's

\section{HRSG/Steam Turbines}

(1) Composite curve with minimum delta $\mathrm{T}$ of $28^{\circ} \mathrm{C}\left(50^{\circ} \mathrm{F}\right)$. (Consistent with NETL case, as modeled by ChemCAD)

(2) Maximum pre-heat of recycled $\mathrm{BFW}$ to $102^{\circ} \mathrm{C}\left(215^{\circ} \mathrm{F}\right)$.

(3) HRSG flue gas discharge temp $=141^{\circ} \mathrm{C}+/-1^{\circ} \mathrm{C}\left(285^{\circ} \mathrm{F}+/-2^{\circ} \mathrm{F}\right)$ (consistent with NETL case, as modeled by ChemCAD)

(4) HRSG HEX pressure drops from NETL Texaco case. 
Table II. IGCC Power Production Case Specific Groundrules and Assumptions.

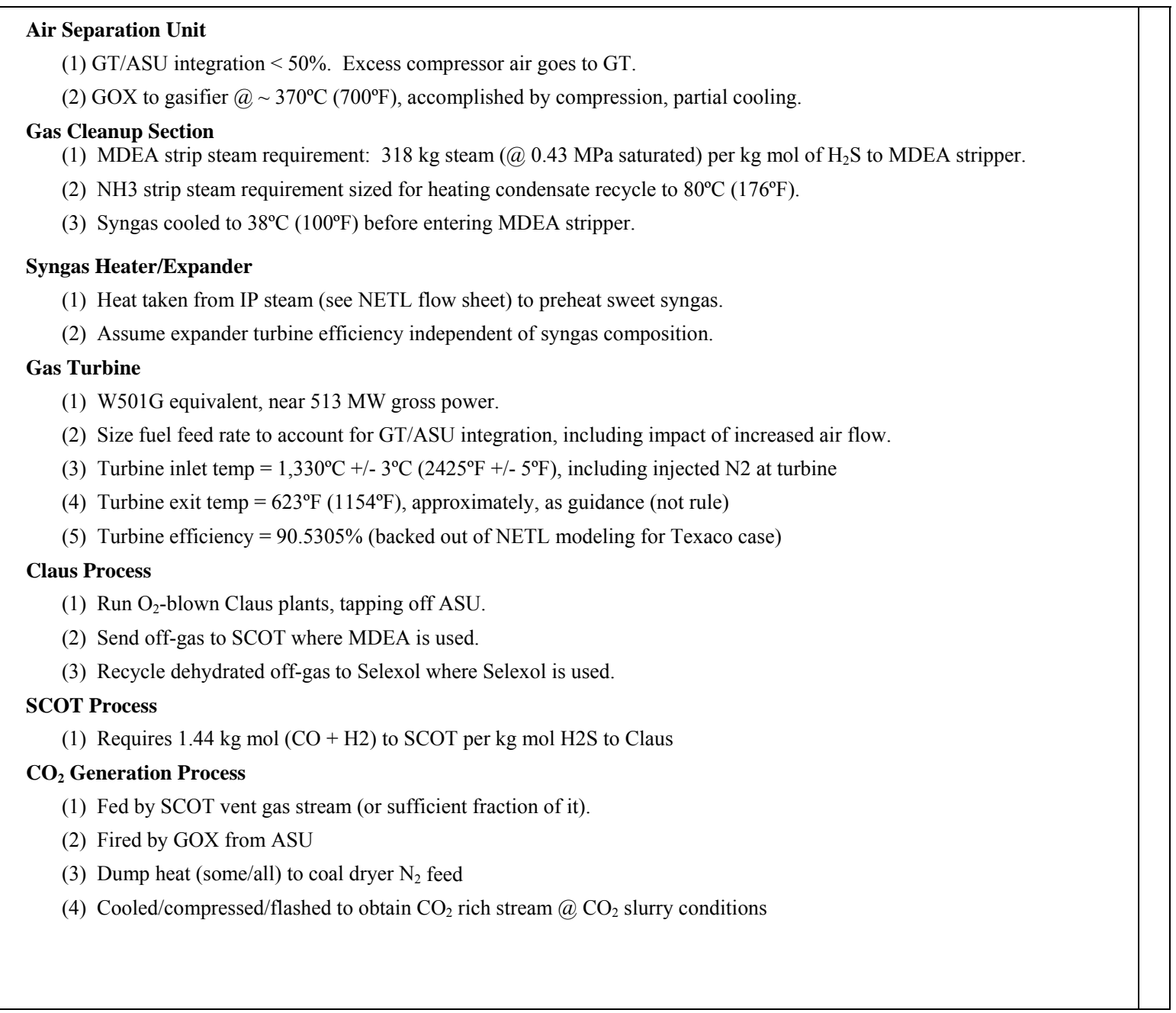


Table III. Hydrogen Production Case Specific Groundrules and Assumptions.

\author{
Air Separation Unit \\ (1) GOX to gasifier @ 370 $\mathrm{C}\left(700^{\circ} \mathrm{F}\right)$, accomplished by compression, partial cooling.

\section{Gas Cleanup Section} \\ (1) $\mathrm{NH} 3$ strip steam requirement sized for heating condensate recycle to $80^{\circ} \mathrm{C}\left(176^{\circ} \mathrm{F}\right)$. \\ (2) Syngas cooled to $38^{\circ} \mathrm{C}\left(100^{\circ} \mathrm{F}\right)$ before entering Selexol columns.
}

\title{
WGS Reactors
}

(1) Steam/dry gas ratio $\sim 1: 1$ (volume fraction)

(2) Recommend margin of $22^{\circ} \mathrm{C}\left(40^{\circ} \mathrm{F}\right)$ above dew point to prevent condensation on catalyst.

-Deluge quench syngas will be saturated upon entry to WGS reactors, for modeling purposes. Practically, superheat required.

- Dry (HEX or partial) quenches will maintain $28^{\circ} \mathrm{C}\left(50^{\circ} \mathrm{F}\right)$ margin out of consideration for candle filters, so not a limiting constraint.

\section{Selexol}

(1) Need $6 \mathrm{MJ}$ of 6 bar steam per kg of S stripped (2.87 lb steam @ 85 psia per lb S)

(2) $2.6 \mathrm{MW}$-sec/kg mol of $\mathrm{CO}_{2}$ and $\mathrm{H}_{2} \mathrm{~S}$ fed to $\mathrm{H}_{2} \mathrm{~S}$ absorber

(3) $3.1 \mathrm{MW}$-sec/kg mol of $\mathrm{CO}_{2}$ absorbed in $\mathrm{CO}_{2}$ absorber

(4) $\mathrm{All} \mathrm{H}_{2} \mathrm{~S}$ removed in $\mathrm{H}_{2} \mathrm{~S}$ absorber (along with other polar compounds), with 1.75:1 $\mathrm{CO}_{2} / \mathrm{H}_{2} \mathrm{~S}$ ratio (molar basis)

(5) Lose $0.1 \%$ of $\mathrm{H} 2$ (and inerts), $0.4 \%$ of $\mathrm{CO}$ in $\mathrm{CO}_{2}$ absorber with $95 \% \mathrm{CO}_{2}$ removal.

\section{$\mathrm{CO}_{2}$ Compression}

(1) 4 stage compressor with interstage cooling to $38^{\circ} \mathrm{C}\left(100^{\circ} \mathrm{F}\right)$, discharging at $15.2 \mathrm{MPa}(2,205 \mathrm{psia})$.

\section{Gas Turbine}

(1) "Rubber" turbine, accommodating PSA purge gas flow.

(2) Can input $\mathrm{N}_{2}$ from ASU, if appropriate.

(3) Turbine inlet temp $=1,330^{\circ} \mathrm{C}+/-3^{\circ} \mathrm{C}\left(2425^{\circ} \mathrm{F}+/-5^{\circ} \mathrm{F}\right)$, including injected $\mathrm{N}_{2}$ at turbine

(4) Turbine exit temp $=688^{\circ} \mathrm{C}\left(1270^{\circ} \mathrm{F}\right)$, approximately, as guidance (not rule)

(5) Turbine efficiency $=81.5 \%$ (accounts for lower performance associated with 7EA-class GT)

\section{Pressure Swing Absorption}

(1) Recovers $90 \%$ of $\mathrm{H}_{2}$ as refinery-grade product $\left(>99 \% \mathrm{H}_{2},<10 \mathrm{ppm} \mathrm{CO}\right)$, delivered at $43^{\circ} \mathrm{C}\left(110^{\circ} \mathrm{F}\right)$ with $0.07 \mathrm{MPa}(10$

psia) pressure drop from inlet

(2) Purge gas delivered at $0.14 \mathrm{MPa}(5 \mathrm{psig}), 32^{\circ} \mathrm{C}\left(90^{\circ} \mathrm{F}\right)$.

\section{Claus Process}

(1) Run air-blown Claus plants.

(2) Recycle dehydrated off-gas upstream of Selexol $\mathrm{H}_{2} \mathrm{~S}$ absorber. 


\section{Results and Discussion}

\section{Power Production}

\section{IGCC Plant Configurations}

Simplified block diagrams for the IGCC configurations for the reference plant and PWR gasifier system configurations are shown in Figures 5 and 6. The key integration difference relative to the reference plant is the removal of the syngas saturator from plants with the PWR gasifier. At the higher operating pressure, the steam mole fraction corresponding to saturation is proportionately lower, and syngas saturation was estimated to not result in a net system benefit. For the $3.4 \mathrm{MPa}$ (500 psia) PWR gasifier case, syngas saturation was added back in to the flowsheet.

\section{IGCC Performance Results}

Table IV presents a summary of performance estimates for the reference case and for various PWR gasifier system configurations. The top rows present plant configuration data as follows:

$\begin{array}{ll}\text { Gasifier Type: } & \text { Texaco, PWR } \\ \text { Feed System: } & \mathrm{H}_{2} \mathrm{O} \text { Slurry, } \mathrm{CO}_{2} \text { Slurry, Dry Pump } \\ \text { Gasifier Liner: } & \text { Refractory, CMC Steam, CMC Insert } \\ \text { Syngas Quench: } & \text { Deluge, Partial, Heat Exchanger (HEX) } \\ \text { Fuel: } & \text { Coal, Petcoke }\end{array}$

Results show a plant efficiency increase of $\sim 3$ percentage points for the PWR gasifier relative to a Texaco gasifier with similar quench configuration. The advantage is $\sim 6$ percentage points with the addition of a Heat Exchanger (HEX) to extract sensible heat from the gasifier effluent prior to syngas cleanup.

For PWR gasifier system configuration options, performance impacts were minimal for the feed system and gasifier liner options considered. No substantial performance difference was found between deluge and partial quench. The HEX quench provides a $3 \%$ performance benefit.

For operation with petcoke, the efficiency is $\sim 2 \%$ lower than for coal with the deluge quench or partial quench configurations, and $\sim 1 \%$ lower for the HEX quench configuration. The efficiency loss is due to the need to operate the gasifier at higher temperatures with petcoke to achieve conversion, resulting in lower cold gas efficiency, increased $\mathrm{O}_{2}$ /carbon ratio, and the larger work function for petcoke grinding and pulverization. The efficiency decrease is less for the HEX quench configuration, as much of the sensible heat generated in the gasifier is recuperated as high pressure steam in the HEX for use in the power island steam turbines.

\section{Availability Results}

The PWR advanced gasifier system is predicted to achieve gasifier availability of $99 \%$. This encompasses the feed, gasifier and quench systems. The primary source of improvement relative to existing IGCC gasifier configurations such as Wabash River and Polk is the increased life and reduced Mean Time To Repair (MTTR) for the gasifier injector and chamber.

The injector life is expected to be $>1$ year, with an MTTR of 6 hours from gasifier shutdown to restart. The MTTR estimate includes removal of reactant feed line connections, coolant connection, and 
injector/chamber flange disassembly, replacement injector installation, and reattachment of feed line connections.

The gasifier chamber life is expected to be $>3$ years, with an MTTR of 24 hours from gasifier shutdown to restart. Chamber MTTR estimates includes 2 hours for system safing, injector removal, chamber removal, new chamber installation, injector installation, 8 hours for gasifier inspection (including leak checks), and 2 hours for system start-up. A schematic of gasifier installation, with chamber removal, is illustrated in Figure 7 . With the $90 \%$ reduction in gasifier volume and replacement of thick refractory brick with a cooled CMC liner, the gasifier weighs much less, making it amenable to installation and removal with an overhead crane. Simplicity of integration is also key to achieving short MTTR.

\section{Cost of Electricity Evaluation}

Overall plant availability, capital cost, performance and cost of electricity (COE) estimates are presented in Table V. The impacts of gasifier configuration options are summarized as follows:

(1) Feed System: The dry pump offers a substantial reduction in capital cost and very slight increase in performance, resulting in a $4 \%$ lower $\mathrm{COE}$ than the $\mathrm{CO}_{2}$ slurry feed system. Comparative reliability evaluation resulted in similar failure rate estimates. Given the greater simplicity of the dry pump, higher availability (hence lower COE) would be expected.

(2) Chamber Liner: The steam cooled channel wall CMC liner was evaluated against the CMC liner insert with cooled channel wall metal jacket for a HEX quench application in order to gauge the "worst case" impact of lost sensible heat for the CMC liner insert case. The $\sim 1 \%$ plant cost reduction with the CMC liner insert more than offsets the $\sim 0.1 \%$ efficiency gain for the steam cooled channel wall CMC liner, resulting in a slightly lower $\mathrm{COE}$ for the CMC liner insert. Qualitatively, the CMC insert approach is also more favorable with regards to technology risk and simplicity of plant integration.

(3) Quench System: The deluge and partial quench systems had the same estimated COE, with slight availability and efficiency advantages for the partial quench system offsetting the capital cost advantage of the deluge quench system. There may be operating cost benefits associated with recovery of slag and fly ash as dry product that is not reflected in the comparison. The HEX quench system, if feasible, would provide the lowest cost of electricity. However, the ability to operate a CMC-based HEX quench system in the trouble-free manner reflected in the availability estimates, and the ability to fabricate, install and integrate the HEX quench within current cost estimates, are uncertain due to the low level of maturity of the technology.

(4) Gasifier Pressure: Operating at 3.4 MPa (500 psia) offered $0.5 \%$ higher efficiency due to addition of the saturator. However, doubling the chamber length to maintain the same residence time resulted in a net increase in $\mathrm{COE}$ for operations at $3.4 \mathrm{MPa}$ (500 psia).

\section{Preferred Configurations}

Based on the results discussed above, three configurations were evaluated for COE impact relative to the reference configurations. These are summarized in Table VI. All three configurations use the CMC liner insert. The near term configurations use a partial quench system and either a $\mathrm{CO}_{2}$ slurry or dry pump system. The $\mathrm{CO}_{2}$ slurry system is believed to present the lowest technology risk for the dry feed system, and as such represents a near term commercial gasifier configuration. However, the dry pump (or similar, such as a Stamet pump) is more desirable from a COE and operational simplicity perspective, and should be baselined if feasibility for operation at commercial scale and conditions is demonstrated. The HEX quench configuration represents a high performance configuration that could be achieved in a subsequent generation of gasifier systems. We view the HEX quench as a follow-on technology that could merit investment after the $\mathrm{CMC}$ technology is validated in the gasifier liner and as the environment that the gasifier will present to the HEX is better characterized.

Based on the gasifier configuration trade study results, a dry pump-fed gasifier with a CMC liner insert and partial quench system was selected as the preferred configuration. This configuration is the basis for hydrogen production plant cases and the evaluation of feedstock impacts in the following section. 
Figure 5. Block diagram for reference IGCC plant configuration.

\section{Power Plant Block Diagram - Texaco Gasifier}

(from NETL study PED-IGCC-98-001)

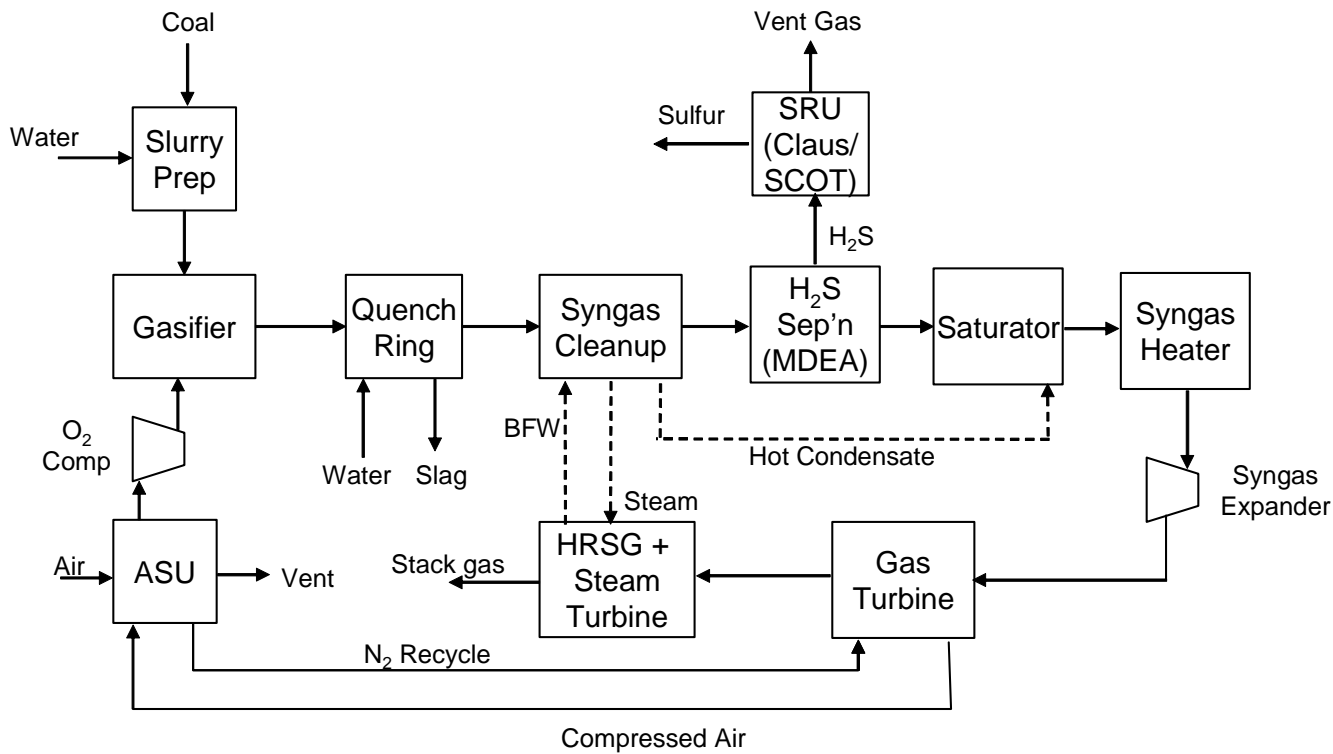

Figure 6. Block diagram for IGCC plant with PWR advanced gasifier. System with HEX quench has Heat Exchanger in place of quench ring, and will provide high pressure steam to steam turbines.

\section{Power Plant Block Diagram - PWR Advanced Gasifier}

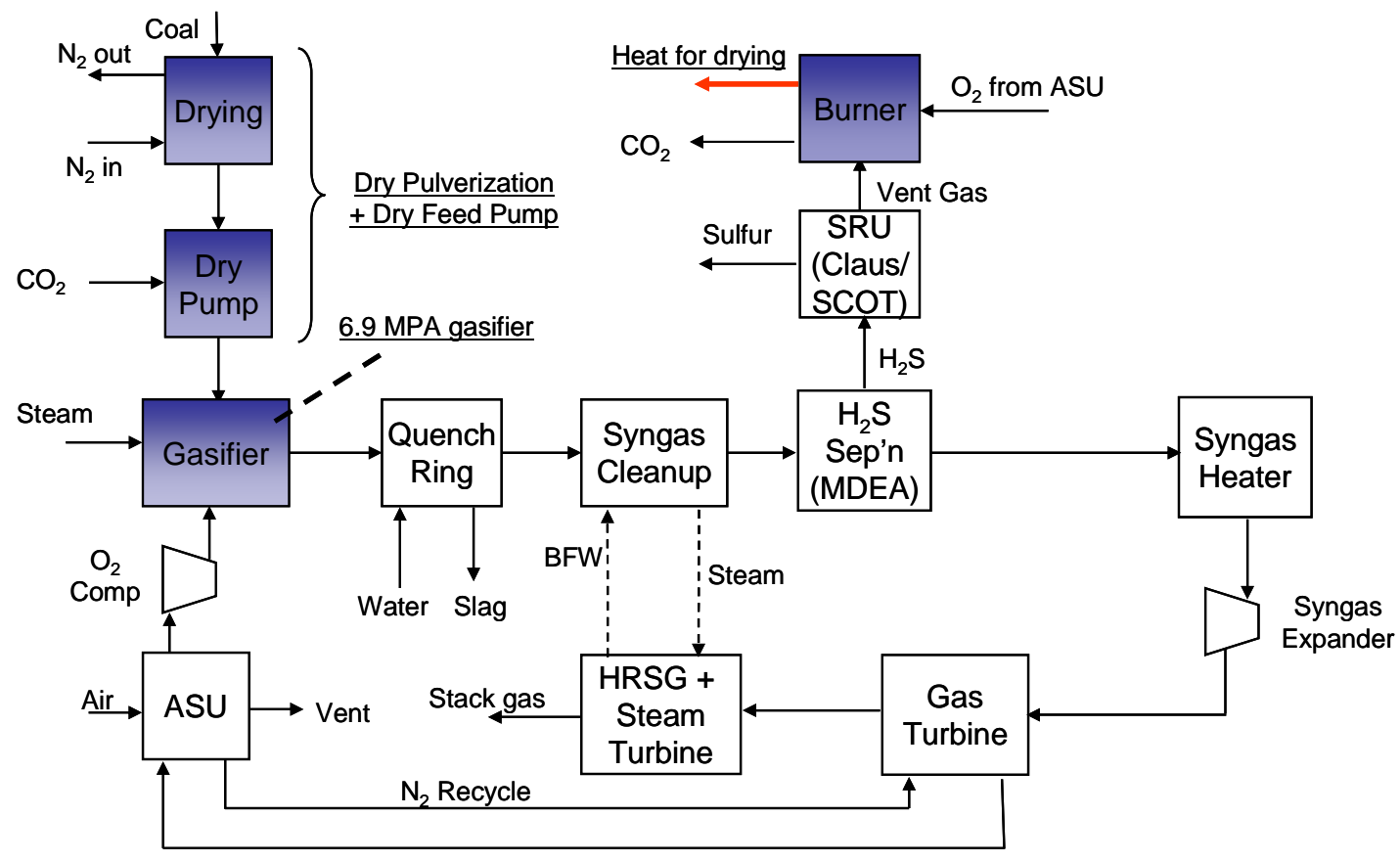

Compressed Air 
Table IV. IGCC performance evaluation for reference case with Texaco gasifier and various PWR advanced gasifier system configurations.

\begin{tabular}{|c|c|c|c|c|c|c|c|c|c|c|c|c|c|c|}
\hline & & NETL Case & AGSD & AGSD & AGSD & AGSD & AGSD & AGSD & AGSD & AGSD & AGSD & AGSD & AGSD & AGSD \\
\hline Gasifier & & Texaco & PWR & PWR & PWR & PWR & PWR & PWR & PWR & PWR & PWR & PWR & PWR & PWR \\
\hline Feed & & H2O Slurry & CO2 Slurry & CO2 Slurry & CO2 Slurry & Dry Pump & CO2 Slurry & CO2 Slurry & CO2 Slurry & CO2 Slurry & CO2 Slurry & CO2 Slurry & Dry Pump & Dry Pump \\
\hline Liner & & Refractory & CMC Steam & CMC Steam & CMC Steam & CMC Steam & CMC Insert & CMC Steam & CMC Steam & CMC Steam & CMC Steam & CMC Insert & CMC Insert & CMC Insert \\
\hline Quench & & Deluge & Deluge & HEX & Partial & Deluge & HEX & Deluge & Partial & HEX & Deluge & Partial & Partial & HEX \\
\hline Fuel & & Coal & Coal & Coal & Coal & Coal & Coal & Petcoke & Petcoke & Petcoke & Coal & Coal & Coal & Coal \\
\hline Other & & & & & & & & & & & $3.45 \mathrm{MPa}$ & & & \\
\hline \multicolumn{2}{|c|}{ Turbine Generation (MW) } & 671.29 & 667.93 & 697.41 & 668.57 & 666.22 & 696.34 & 664.96 & 665.72 & 705.79 & 670.36 & 668.44 & 666.91 & 698.02 \\
\hline & & & & & & & & & & & & & & \\
\hline \multirow{2}{*}{\multicolumn{2}{|c|}{ Compressor Demand (MW) }} & 266.77 & 268.76 & 270.03 & 268.76 & 266.71 & 270.03 & 270.27 & 270.27 & 271.38 & 266.23 & 268.76 & 267.94 & 268.16 \\
\hline & & & & & & & & & & & & & & \\
\hline \multirow{2}{*}{\multicolumn{2}{|c|}{ Pump Demand (MW) }} & 2.25 & 2.36 & 2.43 & 2.20 & 2.30 & 2.40 & 2.30 & 2.23 & 2.48 & 2.24 & 2.24 & 2.20 & 2.40 \\
\hline & & & & & & & & & & & & & & \\
\hline \multicolumn{2}{|c|}{ Plant Losses MW) } & 18.08 & 21.31 & 22.16 & 21.34 & 20.61 & 22.13 & 29.65 & 29.67 & 30.83 & 21.47 & 21.33 & 20.60 & 21.52 \\
\hline \multirow{2}{*}{\multicolumn{2}{|c|}{ Net Power Generated }} & & & & & & & & & & & & & \\
\hline & & 384.2 & 375.5 & 402.8 & 376.3 & 376.6 & 401.8 & 362.7 & 363.6 & 401.1 & 380.4 & 376.1 & 376.2 & 405.9 \\
\hline & & & & & & & & & & & & & & \\
\hline \multirow{2}{*}{\multicolumn{15}{|c|}{ Coal Feed and HHV }} \\
\hline & $\begin{array}{l}\text { and HHV } \\
\text { Feed Rate (kg/hr) }\end{array}$ & 113817 & 102987 & 102987 & 102987 & 102987 & 102987 & 91728 & 91728 & 91728 & 102987 & 102987 & 102987 & 102987 \\
\hline & $\mathrm{HHV}(\mathrm{MJ} / \mathrm{sec})$ & 965.2 & 873.4 & 873.4 & 873.4 & 873.4 & 873.4 & 886.7 & 886.7 & 886.7 & 873.4 & 873.4 & 873.4 & 873.4 \\
\hline & & & & & & & & & & & & & & \\
\hline
\end{tabular}


Figure 7. Plan and elevation for a $113,400 \mathrm{~kg} / \mathrm{hr}$ (3,000 TPD) PWR advanced gasifier, including HEX quench and slag/fly ash removal. Footprint is $18.3 \mathrm{~m}$ by $9.1 \mathrm{~m}$ (60 ft by $30 \mathrm{ft}$ ), with an elevation of $23.6 \mathrm{~m}(77.5 \mathrm{ft})$, and $<21.3 \mathrm{~m}(<70 \mathrm{ft})$ without the HEX.
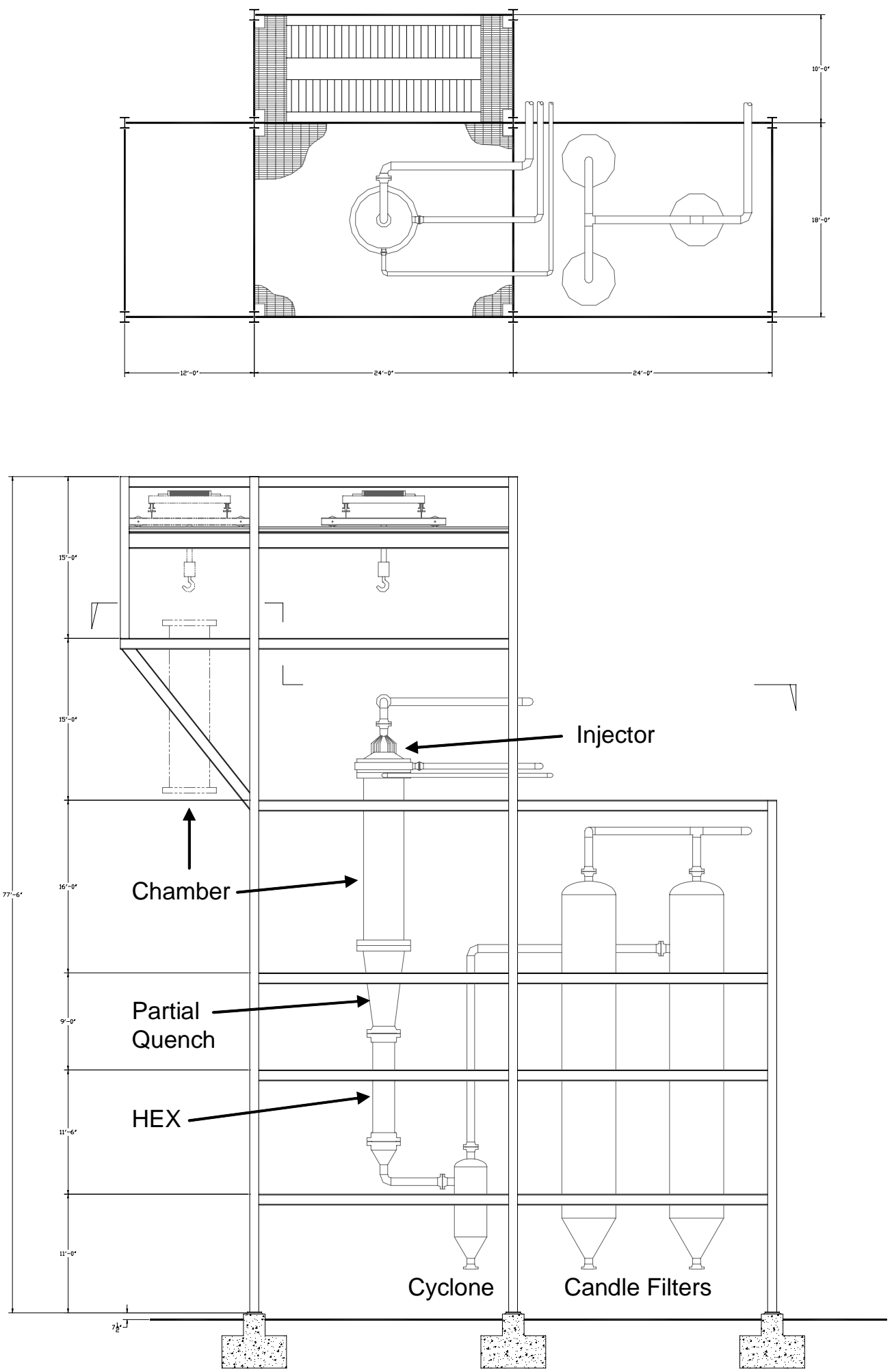
Table V. Availability, capital cost, efficiency and cost of electricity estimates for potential PWR advanced gasifier system configurations.

\begin{tabular}{|c|c|c|c|c|c|}
\hline Configuration & $\begin{array}{c}\text { Plant } \\
\text { Availability }^{(1)}\end{array}$ & $\begin{array}{l}\text { Plant } \\
\text { Cost }^{(2)} \\
(\$ / k W e)\end{array}$ & $\begin{array}{l}\text { Plant } \\
\text { Efficiency } \\
\text { (HHV }\end{array}$ & $\begin{array}{l}\text { Cost of } \\
\text { Electricity } \\
\text { (\$/MW-hr) }\end{array}$ & $\begin{array}{c}\text { Other configuration } \\
\text { attributes }\end{array}$ \\
\hline $\begin{array}{l}\text { NETL Reference } \\
\text { Case (Texaco) }\end{array}$ & $85 \%$ & 1517 & 39.8 & 49.3 & $\begin{array}{l}\text {-Water Slurry } \\
\text { •Refractory Liner } \\
\text { •Deluge Quench }\end{array}$ \\
\hline $\mathrm{CO}_{2}$ Slurry & $93.8 \%$ & 1372 & 43.0 & 41.9 & \multirow{2}{*}{$\begin{array}{l}\text {-Channel Wall CMC Liner } \\
\text {-Deluge Quench }\end{array}$} \\
\hline Dry Pump & $93.8 \%$ & 1298 & 43.1 & 40.3 & \\
\hline $\begin{array}{l}\text { Channel Wall } \\
\text { CMC Liner }\end{array}$ & $94.0 \%$ & 1344 & 46.1 & 40.4 & \multirow[t]{2}{*}{$\begin{array}{l}\text { - } \mathrm{CO}_{2} \text { Slurry } \\
\text { •HEX Quench }\end{array}$} \\
\hline CMC Liner Insert & $94.0 \%$ & 1332 & 46.0 & 40.1 & \\
\hline Deluge Quench & $93.8 \%$ & 1372 & 43.0 & 41.9 & \multirow{3}{*}{$\begin{array}{l}\text { - } \mathrm{CO}_{2} \text { Slurry } \\
\text {-Channel Wall CMC Liner }\end{array}$} \\
\hline Partial Quench & $94.2 \%$ & 1381 & 43.1 & 41.9 & \\
\hline HEX Quench & $94.0 \%$ & 1344 & 46.1 & 40.4 & \\
\hline $\begin{array}{l}3.45 \mathrm{MPa}(500 \\
\text { psia) System }\end{array}$ & $93.8 \%$ & 1395 & 43.6 & 42.2 & $\begin{array}{l}-\mathrm{CO}_{2} \text { Slurry } \\
\text { - Channel Wall CMC Liner } \\
\text {-Deluge Quench }\end{array}$ \\
\hline
\end{tabular}

(1) Assumes $5 \%$ unavailability for rest of plant

(2) Total capital requirement (owner's cost), CY 2004 \$'s

(3) CY 2004 \$'s, $10^{\text {th }}$ year levelized

Table VI. "Best” PWR gasifier system configurations, plant attributes, and COE benefit relative to reference plant. The "Dry Pump + CMC Insert + Partial Quench" configuration was selected as the preferred configuration for near term commercialization.

\begin{tabular}{|c|c|c|c|c|c|}
\hline Configuration & $\begin{array}{c}\text { Gasifier } \\
\text { Availability }\end{array}$ & $\begin{array}{c}\text { Cost } \\
\text { (\$/kWe) }\end{array}$ & $\begin{array}{c}\text { Efficiency } \\
\text { (HHV Basis) }\end{array}$ & $\begin{array}{c}\text { COE } \\
\text { (\$/MW-hr) }\end{array}$ & $\begin{array}{c}\text { COE } \\
\text { Reduction }\end{array}$ \\
\hline $\begin{array}{c}\mathrm{CO}_{2} \text { Slurry Pump + CMC } \\
\text { Insert + Partial Quench }\end{array}$ & $99.2 \%$ & 1367 & $43.1 \%$ & 41.6 & $15 \%$ \\
\hline $\begin{array}{c}\text { Dry Pump + CMC Insert + } \\
\text { Partial Quench }\end{array}$ & $\mathbf{9 9 . 2 \%}$ & $\mathbf{1 2 9 7}$ & $\mathbf{4 3 . 1 \%}$ & $\mathbf{4 0 . 2}$ & $\mathbf{1 8 \%}$ \\
\hline $\begin{array}{c}\text { Dry Pump + CMC Insert + } \\
\text { HEX Quench }\end{array}$ & $99.0 \%$ & 1267 & $46.1 \%$ & 38.8 & $21 \%$ \\
\hline
\end{tabular}

(1) Relative to NETL reference configuration with Texaco gasifier 


\section{Hydrogen Production}

\section{Hydrogen Plant Configurations}

Simplified block diagrams for the hydrogen plant configurations for the reference plant and PWR gasifier system configurations are shown in Figures 8 and 9. The PWR gasifier system configuration consists of a dry pump feed system, a CMC liner insert, and a partial quench system. Four feedstocks were evaluated with the PWR gasifier: bituminous coal (Illinois \#6, of the same properties as for the power cases), petroleum coke (Chalmette Refinery, as described in Table 5-3 of Reference 3), a sub-bituminous coal (Powder River Basin) and a lignite. The sub-bituminous and lignite coal compositions were taken from Table 2 of the NETL Quality Guidelines for Energy System Studies (Reference 1). Comparison to the reference configuration is based on Illinois \#6 as the feedstock. Fuel feed rates for the advanced gasifier were as follows:

- $\quad$ 2,830 TPD Illinois \#6 coal with 2\% moisture.

- $\quad 2,450$ TPD petcoke with $2 \%$ moisture

- $\quad 3,790$ TPD sub-bituminous coal with $15 \%$ moisture

- 4,130 TPD lignite with $15 \%$ moisture

\section{Hydrogen Plant Performance Results}

Performance estimates for the reference plant with Illinois \#6 and the PWR gasifier system with all four feedstocks are presented in Table VII for the case with sequestration-ready $\mathrm{CO}_{2}$ capture and in Table VIII where $\mathrm{CO}_{2}$ product is vented to atmosphere. The difference between the two scenarios is that, for the $\mathrm{CO}_{2}$ capture case, the $\mathrm{CO}_{2}$ from the Selexol unit is compressed up to sequestration-ready conditions (as defined in Reference 1), and the plant performance and cost evaluations reflect the additional equipment and power required to meet the requirement.

The PWR gasifier has an overall efficiency increase of $\sim 7 \%$ relative to a Texaco gasifier based plant. The primary source of this increase is use of the dry feed system with $85 \%$ cold gas efficiency, versus approximately $77 \%$ cold gas efficiency for the Texaco gasifier modeled in the NETL reference case. A secondary contribution comes from the reduced power demand at the ASU due to the lower coal feed rate and lower $\mathrm{O}_{2} /$ coal ratio required for the PWR advanced gasifier to produce an equivalent amount of hydrogen.

Overall efficiencies were somewhat lower for the other feedstocks relative to Illinois \#6. Based on gasification kinetics analysis, the gasifier was operated $\sim 110^{\circ} \mathrm{C}\left(200^{\circ} \mathrm{F}\right)$ higher with petcoke than coal to achieve complete conversion within the gasifier, and the steam/fuel ratio was doubled (reducing steam turbine power output). This required a higher $\mathrm{O}_{2}$ /fuel ratio, with resultant reduction in cold gas efficiency and increase in ASU power demand. Petcoke is also more difficult to grind than coal. For the mesh size assumed as part of this study, the petcoke plant required $8 \mathrm{MW}$ additional power for grinding relative to a coal-fueled plant of the same capacity.

Overall efficiency for plants fed with sub-bituminous and lignite fuels were also 1-2 points lower than for the Illinois \#6 case. For analysis purposes, it was assumed that these were dried to $15 \%$ moisture, versus $2 \%$ for the Illinois $\# 6$. This drove an increase in $\mathrm{O}_{2} /$ carbon ratio to achieve slagging temperatures, although this was somewhat offset by avoiding the need to add steam to the gasifier for these feedstocks.

In all cases, the PWR advanced gasifier based systems indicate overall efficiencies above $70 \%$. 
Figure 8. Block diagram for reference hydrogen plant configuration.

\section{$\mathrm{H}_{2}$ Plant Block Diagram - Texaco Gasifier}

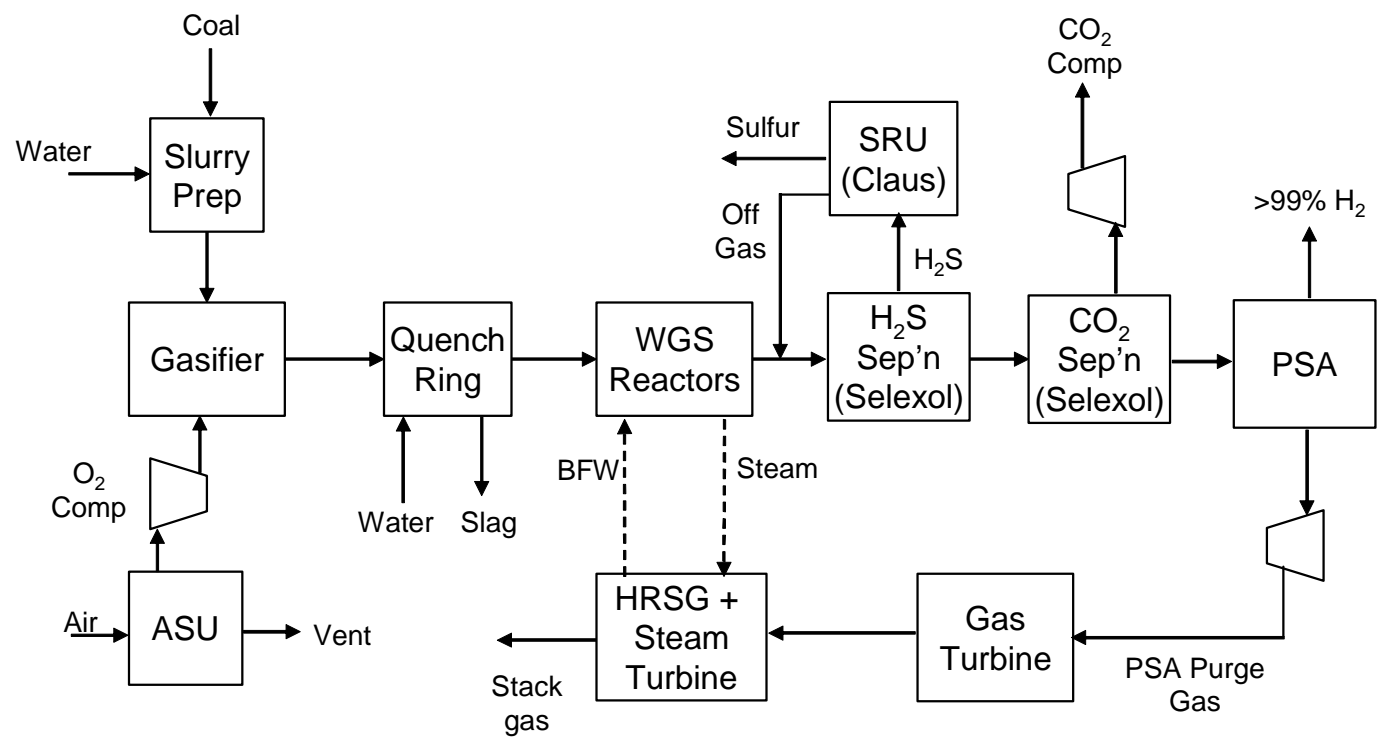

Figure 9. Block diagram for PWR advanced gasifier hydrogen plant configuration.

\section{$\mathrm{H}_{2}$ Plant Block Diagram - PWR Advanced Gasifier}

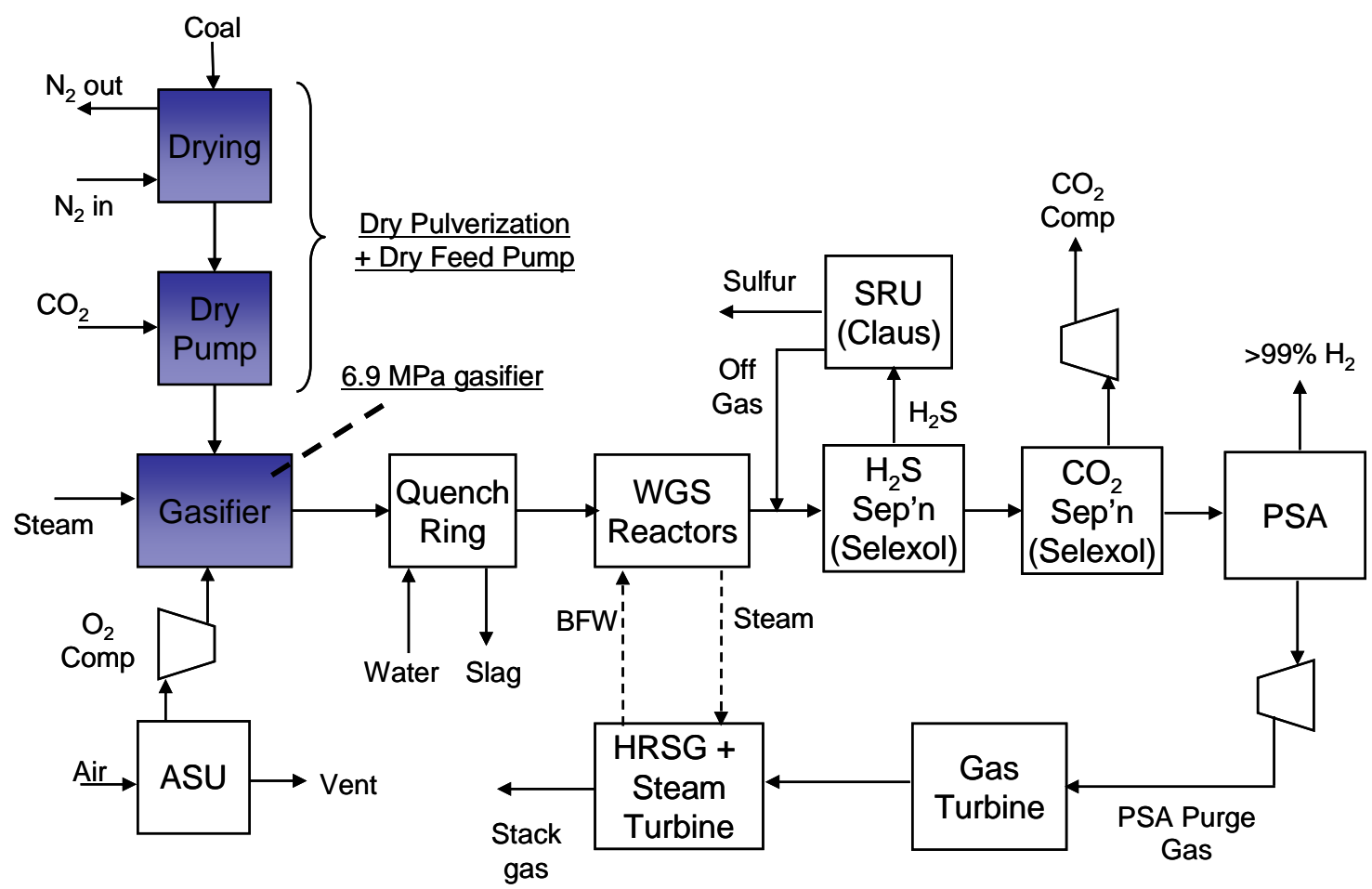


Table VII. Plant performance evaluation with sequestration ready $\mathrm{CO}_{2}$ product, various feedstocks.

\begin{tabular}{|c|c|c|c|c|c|c|}
\hline & & NETL Case & AGSD & AGSD & AGSD & AGSD \\
\hline Gasifier & & Texaco & PWR & PWR & PWR & PWR \\
\hline Feed & & H2O Slurry & Dry Pump & Dry Pump & Dry Pump & Dry Pump \\
\hline Liner & & Refractory & Insert & Insert & Insert & Insert \\
\hline Quench & & Deluge & Partial & Partial & Partial & Partial \\
\hline Fuel & & Coal & Coal & Petcoke & PRB & Lignite \\
\hline \multicolumn{2}{|c|}{ Turbine Generation (MW) } & 102.28 & 101.76 & 92.74 & 105.93 & 126.07 \\
\hline \multicolumn{2}{|c|}{ Compressor Demand (MW) } & 101.05 & 90.20 & 90.85 & 97.05 & 103.22 \\
\hline & & & & & & \\
\hline \multicolumn{2}{|c|}{ Pump Demand (MW) } & 0.83 & 1.04 & 1.17 & 1.09 & 1.03 \\
\hline \multicolumn{2}{|c|}{ Plant Losses, Misc. (MW) } & 21.13 & 22.98 & 32.19 & 25.13 & 25.81 \\
\hline & & & & & & \\
\hline \multicolumn{2}{|c|}{ Net Power Generated (MW) } & -20.7 & -12.5 & -31.5 & -17.3 & -4.0 \\
\hline \multicolumn{2}{|c|}{ Net H2 Generated (MW, HHV) } & 662.8 & 665.5 & 666.2 & 672.2 & 667.8 \\
\hline & & & & & & \\
\hline \multicolumn{7}{|c|}{ Coal Feed and HHV } \\
\hline & Feed Rate (kg/hr, bone dry) & 113817 & 104725 & 90669 & 143137 & 156205 \\
\hline & $\mathrm{HHV}(\mathrm{MJ} / \mathrm{sec})$ & 965.2 & 888.1 & 894.5 & 921.1 & 943.7 \\
\hline \multicolumn{2}{|c|}{ Electricity Efficiency (HHV) } & $-2.1 \%$ & $-1.4 \%$ & $-3.5 \%$ & $-1.9 \%$ & $-0.4 \%$ \\
\hline \multicolumn{2}{|c|}{ Hydrogen Efficiency (HHV) } & $68.67 \%$ & $74.94 \%$ & $74.48 \%$ & $72.98 \%$ & $70.76 \%$ \\
\hline \multicolumn{2}{|c|}{ Overall Efficiency (HHV) } & $66.52 \%$ & $73.53 \%$ & $70.96 \%$ & $71.10 \%$ & $70.34 \%$ \\
\hline \multicolumn{2}{|c|}{ Hydrogen Product (MMSCFD) } & 167.4 & 169.7 & 168.2 & 169.7 & 168.6 \\
\hline
\end{tabular}

Table VIII. Plant performance evaluation with $\mathrm{CO}_{2}$ vented to atmosphere, various feedstocks.

\begin{tabular}{|c|c|c|c|c|c|c|}
\hline & & NETL Case & $\overline{\text { AGSD }}$ & $\overline{\text { AGSD }}$ & $\overline{\text { AGSD }}$ & $\overline{\text { AGSD }}$ \\
\hline Gasifier & & Texaco & PWR & PWR & PWR & PWR \\
\hline Feed & & H2O Slurry & Dry Pump & Dry Pump & Dry Pump & Dry Pump \\
\hline Liner & & Refractory & Insert & Insert & Insert & Insert \\
\hline Quench & & Deluge & Partial & Partial & Partial & Partial \\
\hline Fuel & & Coal & Coal & Petcoke & PRB & Lignite \\
\hline \multicolumn{2}{|c|}{ Turbine Generation (MW) } & 102.28 & 101.76 & 92.74 & 105.93 & 126.07 \\
\hline & & & & & & \\
\hline \multicolumn{2}{|c|}{ Compressor Demand (MW) } & 79.41 & 70.58 & 69.66 & 75.02 & 80.32 \\
\hline \multicolumn{2}{|c|}{ Pump Demand (MW) } & 0.83 & 1.04 & 1.17 & 1.09 & 1.03 \\
\hline & & & & & & \\
\hline \multicolumn{2}{|c|}{ Plant Losses, Misc. (MW) } & 21.13 & 22.98 & 32.19 & 25.13 & 25.81 \\
\hline & & & & & & \\
\hline \multicolumn{2}{|c|}{ Net Power Generated (MW) } & 0.9 & 7.2 & -10.3 & 4.7 & 18.9 \\
\hline \multicolumn{2}{|c|}{ Net H2 Generated (MW, HHV) } & 662.8 & 665.5 & 666.2 & 672.2 & 667.8 \\
\hline \multicolumn{7}{|c|}{ Coal Feed and HHV } \\
\hline & Feed Rate $(\mathrm{kg} / \mathrm{hr}$, bone dry) & 113817 & 104725 & 90669 & 143137 & 156205 \\
\hline & $\mathrm{HHV}(\mathrm{MJ} / \mathrm{sec})$ & 965.2 & 888.1 & 894.5 & 921.1 & 943.7 \\
\hline \multicolumn{2}{|c|}{ Electricity Efficiency (HHV) } & $0.1 \%$ & $0.8 \%$ & $-1.1 \%$ & $0.5 \%$ & $20 \%$ \\
\hline \multicolumn{2}{|c|}{ Hydrogen Efficiency (HHV) } & $68.67 \%$ & $74.94 \%$ & $74.48 \%$ & $72.98 \%$ & $70.76 \%$ \\
\hline \multicolumn{2}{|c|}{ Overall Efficiency (HHV) } & $68.76 \%$ & $75.74 \%$ & $73.33 \%$ & $73.49 \%$ & $72.77 \%$ \\
\hline
\end{tabular}




\section{Cost of Hydrogen Results}

Cost of hydrogen estimates for the reference plant with Illinois \#6 and the PWR gasifier system with all four feedstocks are presented below as a function of feedstock cost in \$/MMBtu. Figure 10 shows results with sequestration-ready $\mathrm{CO}_{2}$ sold at $\$ 11 /$ metric ton at the plant gate for applications such as enhanced oil recovery (EOR). Figure 11 shows results with delivery of sequestration-ready $\mathrm{CO}_{2}$ at the plant gate with no $\mathrm{CO}_{2}$ sales revenue. Figure 12 shows results for plants where the $\mathrm{CO}_{2}$ is vented to atmosphere. Lines are shown for hydrogen production cost from Steam Methane Reformers (SMR) with natural gas at $\$ 3, \$ 4$ and $\$ 5 / \mathrm{GJ}$ to indicate the estimated production economics relative to existing technology.

For Illinois \#6 at $\$ 1.42 / \mathrm{GJ}(\$ 1.5 / \mathrm{MMBtu})$ with carbon capture via sequestration-ready $\mathrm{CO}_{2}$, the PWR advanced gasifier has a $\$ 0.021 / \mathrm{Nm}^{3}(\$ 0.59 / \mathrm{MSCF})$ advantage relative to a Texaco gasifier, decreasing $\mathrm{H} 2$ sales price from $\$ 0.107 / \mathrm{Nm}^{3}$ ( $\left.\$ 3.03 / \mathrm{MSCF}\right)$ to $\$ 0.086 / \mathrm{Nm}^{3}$ (\$2.44/MSCF).

For a given $\$ / G J$ fuel cost, the sub-bituminous and lignite fuels ranged from $\$ 0.001-\$ 0.004 / \mathrm{Nm}^{3}(\$ 0.04$ $\$ 0.12 / \mathrm{MSCF}$ ) higher $\mathrm{H}_{2}$ cost relative to Illinois \#6, with the difference increasing with increased fuel cost. However, from a market-based perspective, given the historical $\$ / G J$ spread between bituminous coals and sub-bituminous coals or lignite, the lower grade fuels could offer more favorable economics.

Hydrogen generated with petroleum coke consistently ran $\$ 0.005 / \mathrm{Nm}^{3}$ (\$0.15/MSCF) higher than with Illinois $\# 6$ at the same $\$ / G J$ value. This was driven in large part by increased plant power consumption by the petroleum coke plant together with larger capital outlays for acid gas removal and Claus process equipment. However, as with the low rank coals, petroleum coke tends to trade at a substantial \$/GJ discount relative to bituminous coals, making it a potentially more attractive feedstock.

Hypothetically, a plant could be designed that would burn all ranks of feedstock evaluated in this study. However, design capacity for various plant components would be dictated by specific feedstocks. For example, drying, gasifier and $\mathrm{CO}_{2}$ compression would be sized by the low rank coals; acid gas removal, sulfur recovery, and gasifier steam requirements by petroleum coke. The plant capital cost implications are significant, and would require careful analysis of feedstock economics to justify building a plant that accommodates a broad range of feedstocks. 
Figure 10. Hydrogen sales price versus fuel cost for the reference plant and PWR advanced gasifier, with sequestration-ready $\mathrm{CO}_{2}$ sold for $\$ 11$ metric ton at the plant gate.

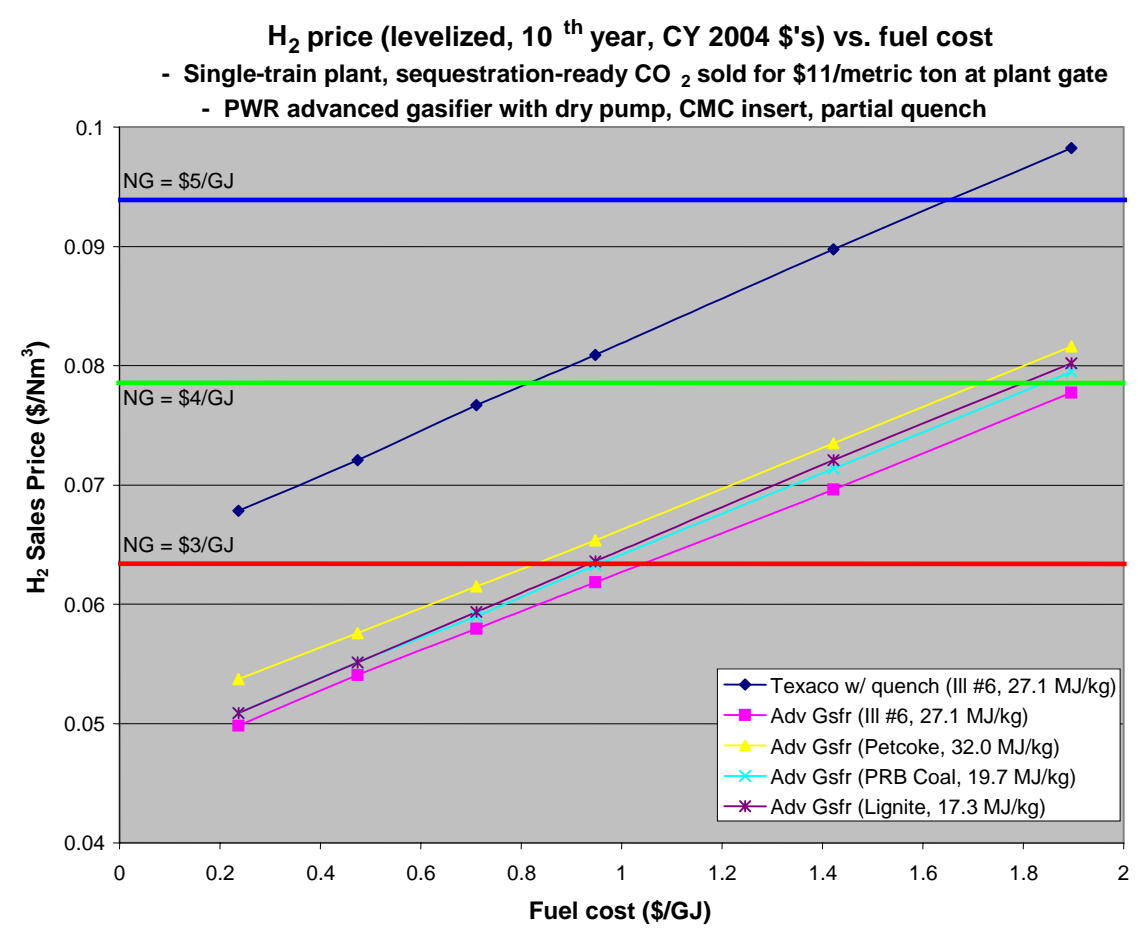

Figure 11. Hydrogen sales price versus fuel cost for the reference plant and PWR advanced gasifier, with sequestration-ready $\mathrm{CO}_{2}$ delivered at the plant gate.

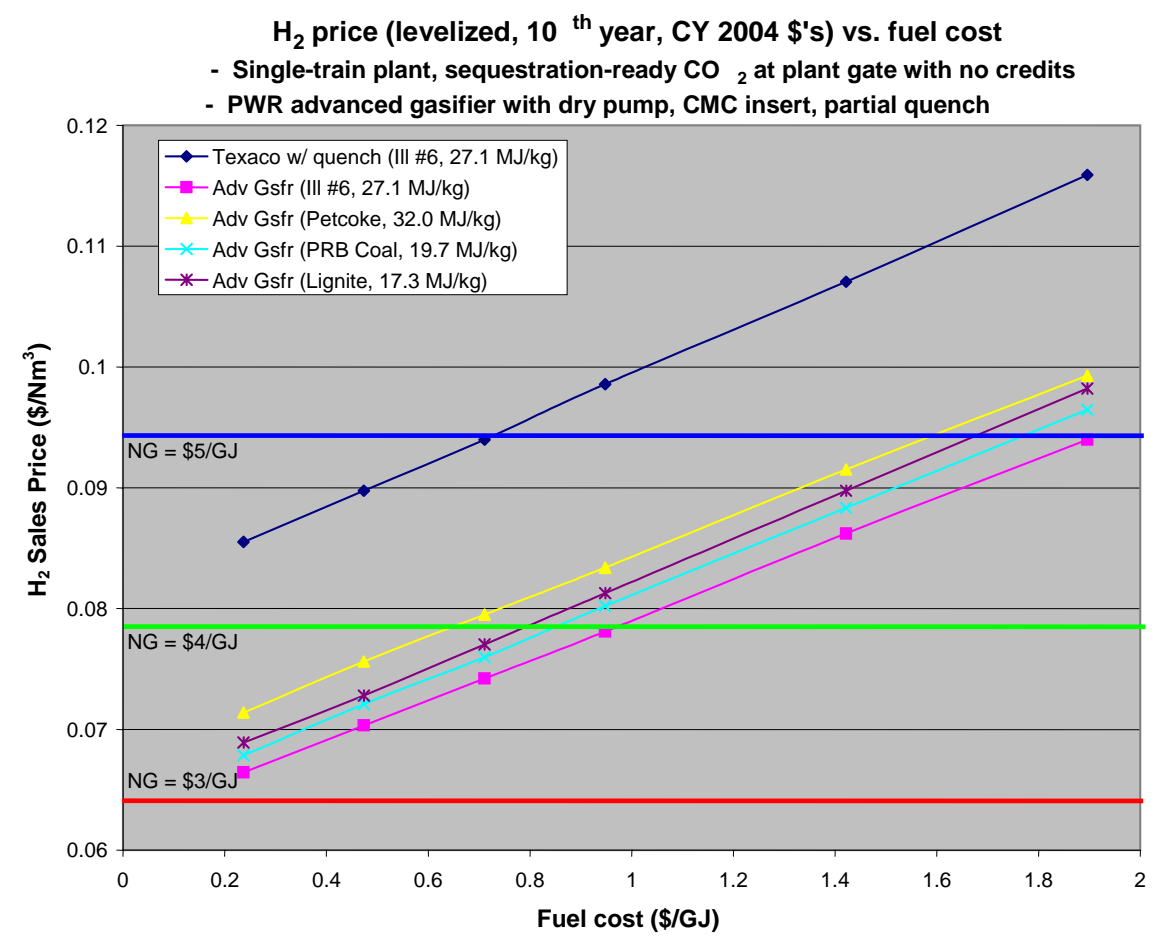


Figure 12. Hydrogen sales price versus fuel cost for the reference plant and PWR advanced gasifier, with $\mathrm{CO}_{2}$ vented to atmosphere.

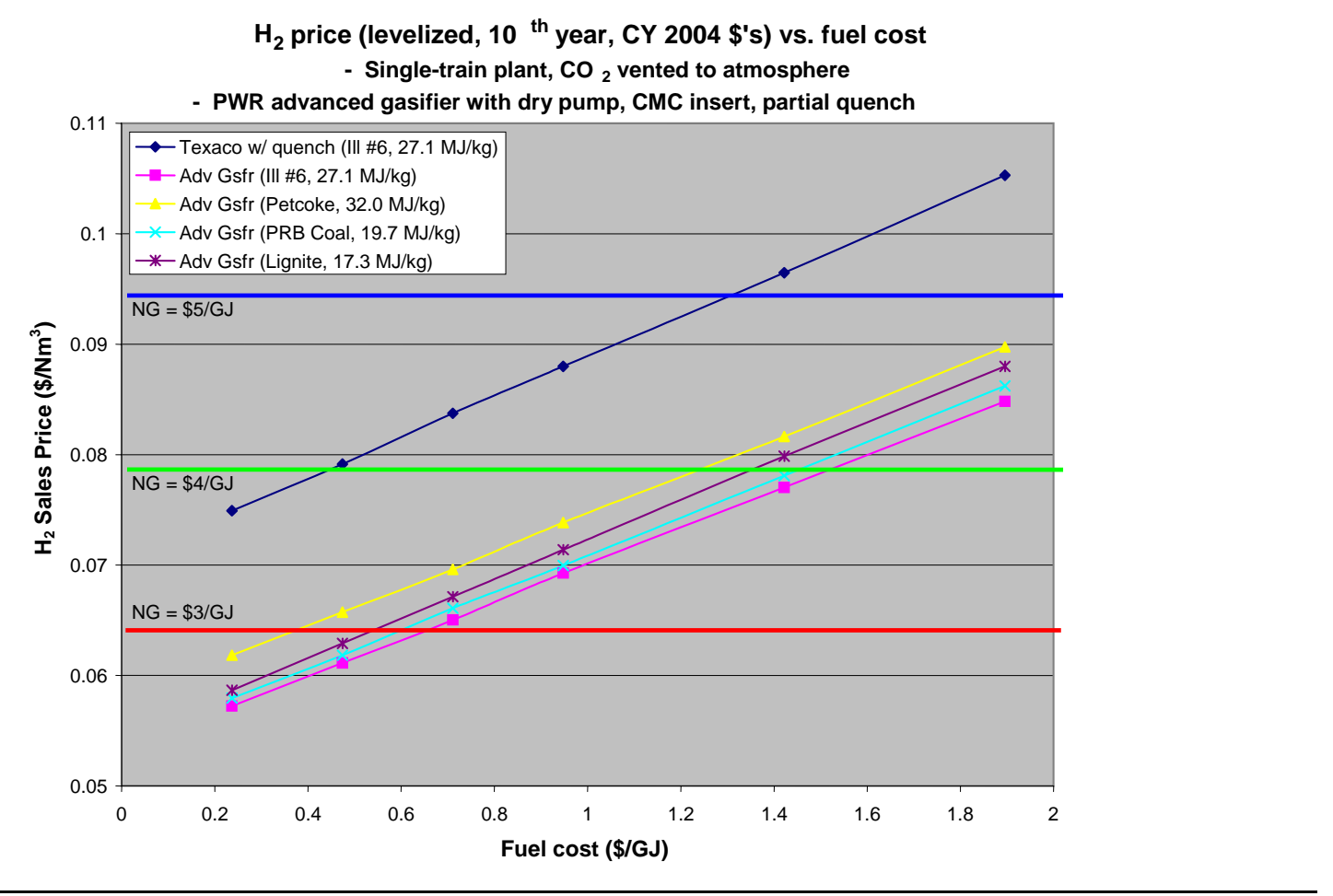




\section{Conclusion}

PWR advanced gasifier technology provides substantial performance, availability, capital cost, and cost of product (electricity and hydrogen) benefits relative to the state-of-the-art Texaco gasifier as modeled in earlier NETL studies. These benefits are summarized in Table IX below. PWR advanced gasifier technology has the potential to decrease capital cost by $15 \%$ and cost of product by $15-20 \%$ for electricity and hydrogen. This is relevant to achieving the efficiency, availability, plant capital costs and cost of electricity goals set out in the Clean Coal Technology Roadmap.

Table IX. Summary of plant-level benefits of PWR advanced gasifier technology relative to a Texaco quench gasifier for power and hydrogen production.

\begin{tabular}{|c|c|c|c|}
\hline Application & $\begin{array}{c}\text { Texaco } \\
\text { Quench }\end{array}$ & PWR & Improvement \\
\hline Power & & & \\
\hline Capital Cost (\$/KWe) & 1517 & 1297 & $14.5 \%$ \\
\hline Cost of Electricity (\$/MWh) & 49.3 & 40.2 & $18.5 \%$ \\
\hline Efficiency (HHV, \%) & $39.8 \%$ & $43.1 \%$ & $3.3 \mathrm{pts}$ \\
\hline Plant Availability (\%) & $85 \%$ & $94 \%$ & 9 pts \\
\hline Hydrogen & & & \\
\hline Capital Cost (\$/KWth) & 870 & 739 & $15.1 \%$ \\
\hline Cost of Hydrogen (\$/Nm3) & 0.107 & 0.086 & $19.5 \%$ \\
\hline Cost of Hydrogen (\$/GJ) & 8.45 & 6.79 & $19 . \%$ \\
\hline Efficiency (HHV, \%) & $66.5 \%$ & $73.5 \%$ & 7.0 pts \\
\hline Plant Availability (\%) & $85 \%$ & $94 \%$ & 9 pts \\
\hline
\end{tabular}




\section{ADVANCED GASIFIER PILOT PLANT DEFINITION}

\section{Approach}

\section{Requirements Development}

Pilot plant requirements were defined to incorporate the features of the preferred commercial gasification plant configuration identified in the Advanced Commercial Gasifier Concepts task. A comparison of pilot plant and commercial gasifier attributes is presented in Table X. For purposes of developing pilot plant concept costs, it was assumed that the test campaign would accumulate 1,000 hours of hot-fire test time.

Table $\mathrm{X}$. The pilot plant gasifier concept requirements were selected to best reflect the commercial gasifier configuration.

\begin{tabular}{|c|c|c|c|}
\hline Attribute & $\begin{array}{l}\text { Commercial } \\
\text { Gasifier }\end{array}$ & Pilot Plant & Comments \\
\hline Feed System & Dry pump & Dry pump & $\begin{array}{l}\text { - STAMET pump selected as basis for } \\
\text { pilot plant } \\
\text { - Also considered piston pump }\end{array}$ \\
\hline Liner & CMC Insert & CMC Insert & \\
\hline Quench & Partial & Partial & \\
\hline Fuel & All ranks coal & $\begin{array}{l}\text { Bituminous, } \\
\text { PRB }\end{array}$ & $\begin{array}{l}\text { - Potential for subsequent } \\
\text { demonstration with lignite, petcoke }\end{array}$ \\
\hline Feed Rate & 3,000 TPD & 18 TPD & $\begin{array}{l}\text { - Pilot plant facility limit } \\
\text { - } 20 \% \text { scale of single commercial-scale } \\
\text { gasifier injector element }\end{array}$ \\
\hline Pressure & 1,000 psia & 400 psia & - Pilot plant facility limit \\
\hline Residence Time & $0.5 \mathrm{sec}$ & $0.2-0.5 \mathrm{sec}$ & $\begin{array}{l}\text { - Pilot plant provides flexibility to assess } \\
\text { impact of residence time }\end{array}$ \\
\hline
\end{tabular}

Specific pilot plant gasifier and feed system requirements were developed to document the design requirements for concept development.

\section{Concept Definition}

Pilot plant concept definition was performed by a team comprised of Pratt \& Whitney Rocketdyne (PWR), Gas Technology Institute (GTI), and Stamet personnel. The concept definition process used is defined as follows:

(1) Develop mass and energy balances

Detailed mass and energy balances for the feed system and gasifier were developed using ChemCAD 5.3.0. These mass and energy balances were updated as concept definition progressed to reflect thermal analysis of the gasifier, with subsequent updates to design requirements documents.

(2) Define gasifier concept

Preliminary gasifier component (injector, liner, chamber, quench ring, etc.) and gasifier assembly CAD layouts were developed based on design requirements using ProE. These layouts included design details required for initial thermal, stress and mechanical analysis of the components to ensure feasibility of the concept. These details also enabled subsequent assessment for part manufacturability.

Materials of construction were evaluated based on previous PWR gasification experience, commercial availability for large scale gasifiers, NACE publication MR0175 recommendations, ability to 
withstand potential formation of corrosive condensates during start-up and shut-down, previous experience at PWR in welding and/or brazing the material, and cost.

Computational Fluid Dynamic (CFD) modeling of the pilot plant gasifier was performed using a FLUENT model incorporating an improved Probability Density Function (PDF) and a more complex finite rate kinetics modeling of the injection/gasification process. This model was used to guide injector design, providing insight into ignition and flameholding for a given injector configuration and entering reactant conditions.

Computer models generated from component CAD layouts were used for stress and thermal analysis of components. Stress analysis was used to confirm that the part could be manufactured and would withstand induced loads during operation either due to pressure differentials or thermal growth of the hardware. Thermal analysis was performed to ensure that the gasifier chamber metal surfaces would remain within a temperature range consistent with commercial gasifier life goals, and to assess heat transfer through and temperature drop across the $\mathrm{CMC}$ inserts. A dynamic mechanical analysis was performed on a model of the CMC liner to quantify potential loads induced by pressure transients within the gasifier. The component CAD layouts were updated based on these analyses to arrive at a feasible gasifier concept.

PWR manufacturing personnel provided inputs during component layout development to ensure that each part was within PWR manufacturing capabilities, and that it could be inspected to verify compliance with quality assurance standards. Manufacturing process flow logic was developed to define each step in component manufacture. A preliminary Bill Of Material (BOM) was prepared based on component layouts and the quantity of each part needed for the pilot plant.

\section{(3) Define feed system concept}

Feed system concept definition started with a trade study to evaluate which dry feed system pump approach had the best prospects for commercial evaluation. Four feed system pump approaches were considered: The Stamet Posimetric pump; a piston-pump design previously demonstrated in testing at NETL; a patented PWR $\mathrm{CO}_{2}$ slurry system; and a proprietary PWR dry pump. The four options were evaluated based on scalability, cost, performance, availability, fuel flexibility, turndown, and development schedule. Based on the available technical data for the four options, the Stamet pump rated highest. The proprietary PWR pump, which is at the concept level, could provide superior scalability, performance, fuel flexibility and cost relative to the Stamet pump. However, it should be demonstrated to a level of maturity comparable to the Stamet pump before warranting selection as the preferred commercial dry coal feed pump.

Stamet was placed under contract to develop technical definition of a low pressure hopper and dry feed pump system corresponding to the pilot plant feed system requirements document. This included a CAD model of the feed system, preliminary P\&ID, preliminary control logic, cost estimate for design/build/test, and schedule.

PWR personnel defined the remainder of the feed system, including the high pressure coal tank, feed valve, pressurization and purge lines and valves, main valve, flow indication, and other instrumentation. Equipment design incorporated lessons learned from previous dense phase feed work at PWR to minimize the potential for bridging and plugging in the dense phase system. A preliminary high pressure tank drawing was developed and submitted for quotes to vendors. A list of valves, instrumentation, and miscellaneous equipment for the feed system was prepared, and vendor quotes obtained.

\section{(4) Define balance of plant concept}

For the purpose of developing a cost estimate for the pilot plant concept, PWR evaluated Greenfield versus existing test facilities. Requests for Proposal were sent to potential sites with existing facilities prior to the start of this project for definition of the pilot plant concept as well as for performance of the overall pilot plant demonstration program. An evaluation of responding test sites was performed based on an assessment of technical capabilities at each site (existing infrastructure suitable for the 
pilot plant, personnel experience, and recent experience in bringing similar facilities on-line) as well as the estimated cost for performing the pilot plant project at a given site. This evaluation identified the Gas Technology Institute (GTI) as the "best value" site for purposes of generating a cost estimate in support of the current project. GTI was subsequently put under contract to PWR to perform pilot plant concept definition.

The key process equipment in the balance of plant encompasses coal supply, nitrogen supply, reactant supply, gasifier coolant, and gas handling subsystems. It also encompasses structures required to accommodate the pilot plant gasifier as well as plant control systems.

GTI, Stamet and PWR personnel collaborated to develop an integrated pilot plant concept. This included development of preliminary Process Flow Diagrams (PFD's), Piping and Instrumentation Diagrams (P\&ID's), equipment lists, interface definition, plot plan and elevation drawings, and startup/shut-down sequences. These data served as the basis for delineating scope between GTI, Stamet and PWR, and supported subsequent cost and schedule estimates.

\section{(5) Schedule Estimate}

The pilot plant schedule estimate was based on assessments by each team member (PWR, GTI and Stamet) for the time required to perform their respective tasks. PWR gasifier design schedule was based on the estimated number of drawings and comparable schedule requirements from previous programs. Gasifier fabrication schedule was based on detailed manufacturing task build-up developed by senior PWR manufacturing personnel. Feed system design schedule was based on a detailed task build-up, with estimated duration for each task. Feed system procurement schedule was based on vendor quotes for major components (including Stamet). Schedule slack was placed between anticipated fabrication/procurement completion dates and start of feed system and gasifier integration dates to provide opportunity for recovery in the event of schedule disruptions. Balance of plant design and build schedule was developed by GTI based on pilot plant concept definition and recent experience with design and build of the Flex-Fuel Test Facility (FFTF) at GTI, with account made of prevailing local weather conditions when foundation and structural work is in progress. The gasifier test schedule was developed based on detailed task build-up for gasifier integration and check-out and a preliminary test plan, along with recent actual experience from gasifier testing at the FFTF.

\section{(6) Cost Estimating}

Cost estimates were developed for the design, fabrication and test operations of the gasifier pilot plant. Design and fabrication estimates were based on pilot plant concept definition results. Test operation costs were estimated based on a preliminary test plan.

Costs estimates were scoped relative to a "Work Breakdown Structure" (WBS), as shown in Figure 13. Within each of the major WBS elements, costs were estimated for material, labor, and other costs. Material cost estimates included major subcontracts (GTI and Stamet), feed system equipment, and gasifier material. Labor estimates were for PWR effort directly attributed to each WBS element. Other costs were those that could not be attributed directly to a WBS element (such as program management and reporting) or costs that were neither material nor labor (such as travel). 


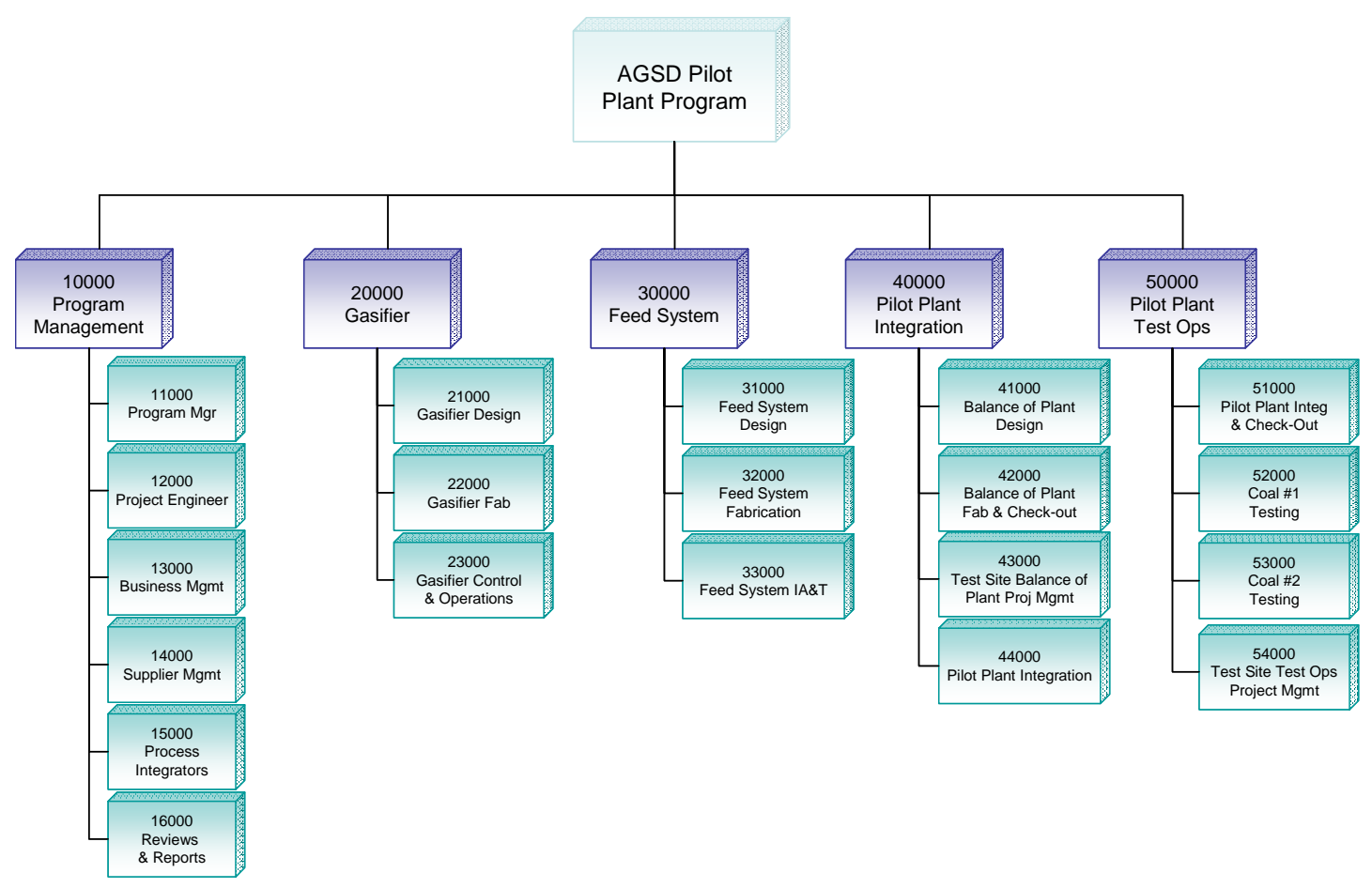

Figure 13. Work Breakdown Structure (WBS) for the gasifier pilot plant cost estimate.

GTI and Stamet developed cost estimates for their areas of responsibility based on pilot plant concept technical definition together with Statements of Work delineating specific responsibilities for pilot plant design, build, and test operations. Gasifier material costs were based on vendor quotes for material identified in the gasifier BOM. Feed system material costs were developed from the equipment list, obtaining vendor quotes for major cost elements (such as the flexible bellows, high pressure tank, feed valve, and flow indicator) or from catalog price data for valves and instrumentation. Pilot plant test operations costs were based on an assumed total hot-fire test time of 1,000 hours, firing on bituminous or sub-bituminous coals.

PWR labor estimates were based on pilot plant technical definition and a detailed WBS dictionary defining the scope within each WBS element. Gasifier design labor was primarily factored from the number and relative complexity of drawings required for detailed design, using actual data from previous combustion devices design efforts. Labor for groups supporting the design effort (analysis, materials engineer, quality engineer, manufacturing engineer, etc.) were factored from the combustion devices design labor estimate, again based on actuals from previous programs. Gasifier fabrication labor was based on a detailed task build-up from PWR manufacturing personnel, along with past actuals for similar operations factored for relative complexity. Feed system design and fabrication labor was based on a detailed task build-up, as were pilot plant test operations support estimates.

Program management and reporting labor estimates were based on actuals from past PWR programs, with specific estimates for supplier management personnel based on recent large subcontracts within the PWR Power Systems group. Travel was estimated for each WBS element, with emphasis on having PWR personnel on-site once or twice per month at GTI throughout the program, with extended presence during gasifier test operations. 


\section{Results and Discussion}

\section{Pilot Plant Concept Overview}

A block flow diagram for the pilot plant is shown in Figure 14, depicting the major process elements. Coal feed is supplied via pneumatic transfer from an existing coal silo at GTI into the low pressure coal hopper supplied by Stamet as an integrated package with the Stamet Posimetric pump. The pump discharges coal into the high pressure coal hopper supplied by PWR, where nitrogen transport gas conveys coal as a dense phase $(\varepsilon \sim 60 \%)$ from the high pressure tank to the gasifier injector. Oxygen and steam are mixed and fed to the gasifier injector, rapidly and thoroughly mixing with the coal shortly after entering the chamber. A conceptual drawing of the pilot plant gasifier is shown in Figure 15. Oxygen, steam and coal react along the length of the plug flow gasifier, with a maximum residence time of 0.5 seconds. As it enters the quench ring, the gasifier product is at slagging temperatures $\left(\sim 1,400^{\circ} \mathrm{C}\right)$, where water spray partially quenches the raw syngas to $\sim 540^{\circ} \mathrm{C}$. Existing syngas processing equipment at GTI removes the slag and fly ash from the syngas, followed by sulfur removal, and then flaring of the syngas to atmosphere. Process Flow Diagrams depicting the major equipment and major process streams for the pilot plant are shown in Figures 16 and 17. Battery limit process stream data for normal operating conditions with Illinois \#6 coal are shown in Table XI. Battery limit process stream data for normal operating conditions with Powder River Basin coal are shown in Table XII.

The pilot plant gasifier concept is scalable and traceable to a commercial scale $(\sim 3,000 \mathrm{TPD})$ plant. The single pilot plant injector element is at $1 / 5^{\text {th }}$ the scale (mass flow rate basis) of a commercial scale injector element, well within the typical range of rocket engine-style injector scaling of 4:1 to 40:1. The pilot plant gasifier chamber length, at approximately $5 \mathrm{~m}(15 \mathrm{ft})$, is the same as expected for the commercial scale gasifier, with the same residence time $(0.5 \mathrm{sec})$. Analysis indicates that thermal environments within the pilot plant gasifier concept are comparable to those expected within the commercial scale gasifier, with regards to actual temperatures, temperature differentials, and heat fluxes. The 1,000 hour cumulative test time is expected to include 10 start-up and shut-down cycles. This will serve as the basis for making injector life (based on cumulative hot fire test time) and CMC life (based on start-up and shut-down cycles) predictions in commercial application. Initial short duration testing will enable screening of "infant mortality" type failure modes. Long duration testing, including start-up and shut-down, will accumulate approximately $10 \%$ of the minimum life exposure requirement for the injector (hours) and CMC liner (start-up/shut-down cycles). Commercial life predictions will be based on post-test hardware inspection and analysis.

The pilot plant concept schedule and cost estimates assume that the feed system and gasifier are housed in a newly built structure at the GTI facility, then tied into the existing syngas processing equipment with refractory lined piping. An elevation view depicting the general arrangement of feed system and gasifier equipment in the new structure is shown in Figure 18. A plot plan view depicting the location of the feed system and gasifier relative to the existing Flex-Fuel Test Facility is shown in Figure 19. 


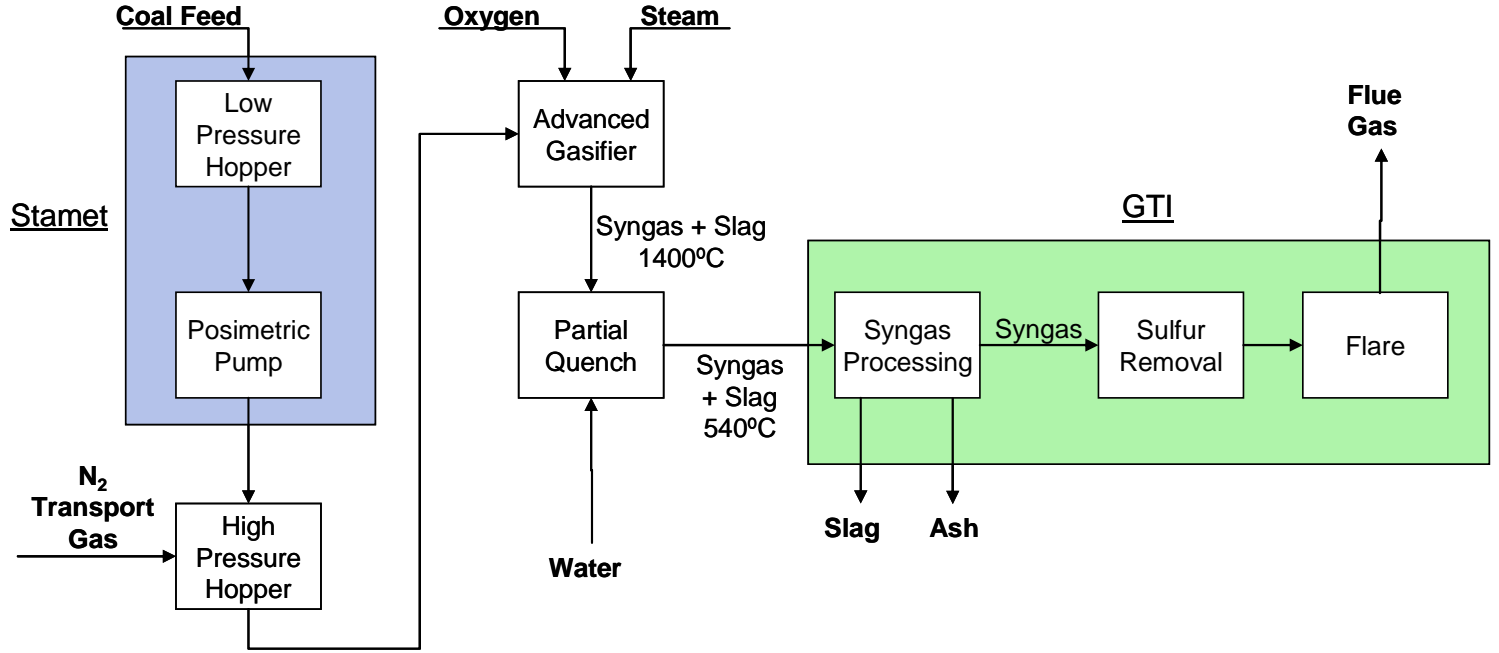

Figure 14. Block flow diagram for the pilot plant gasifier system concept.

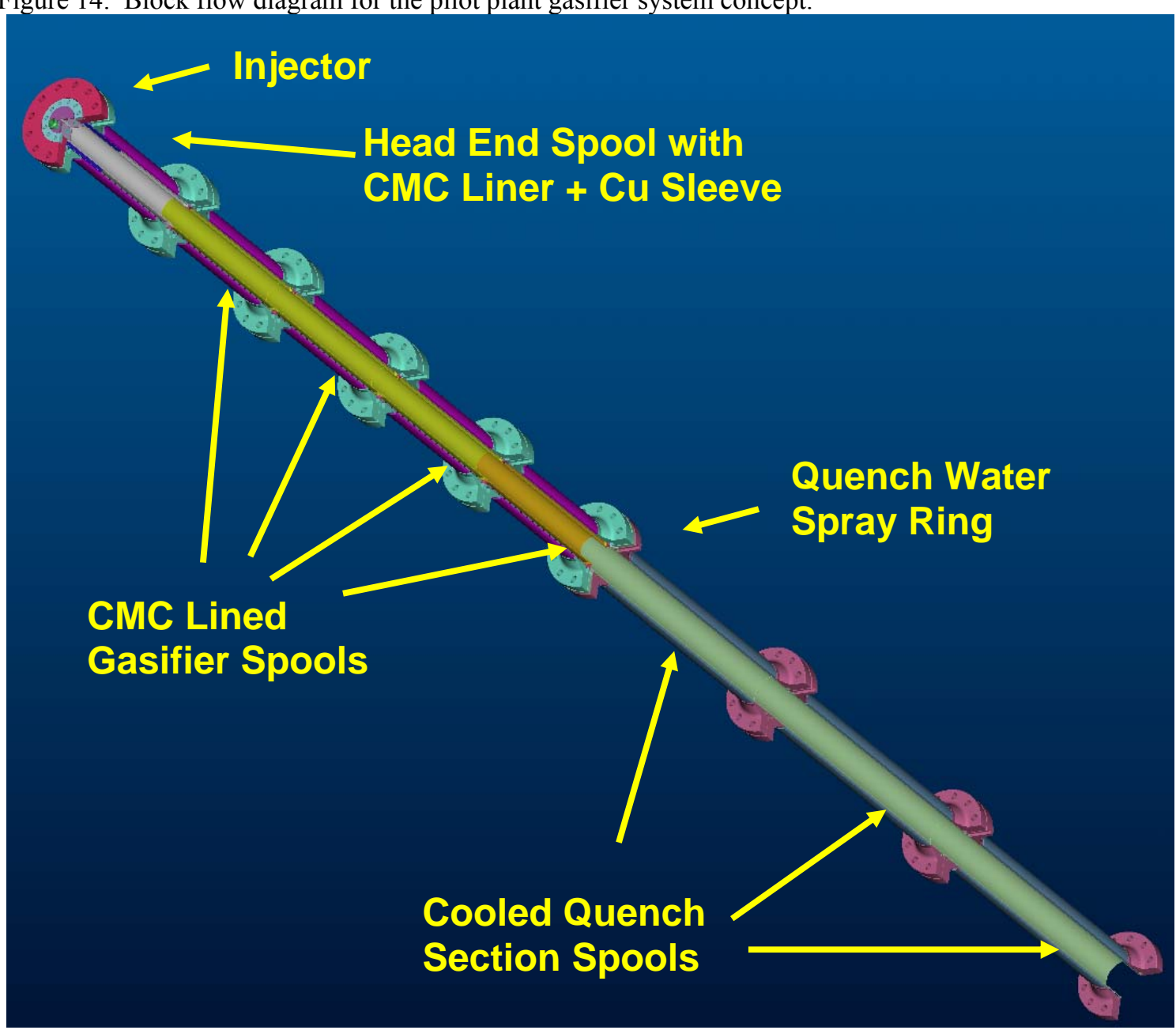

Figure 15. Conceptual drawing of the pilot plant gasifier and quench sections. Approximate dimensions are $10 \mathrm{~m}$ long and $0.3 \mathrm{~m}$ diameter. 
Figure 16. Process flow diagram for the advanced gasifier system pilot plant -feed system and gasifier process equipment.

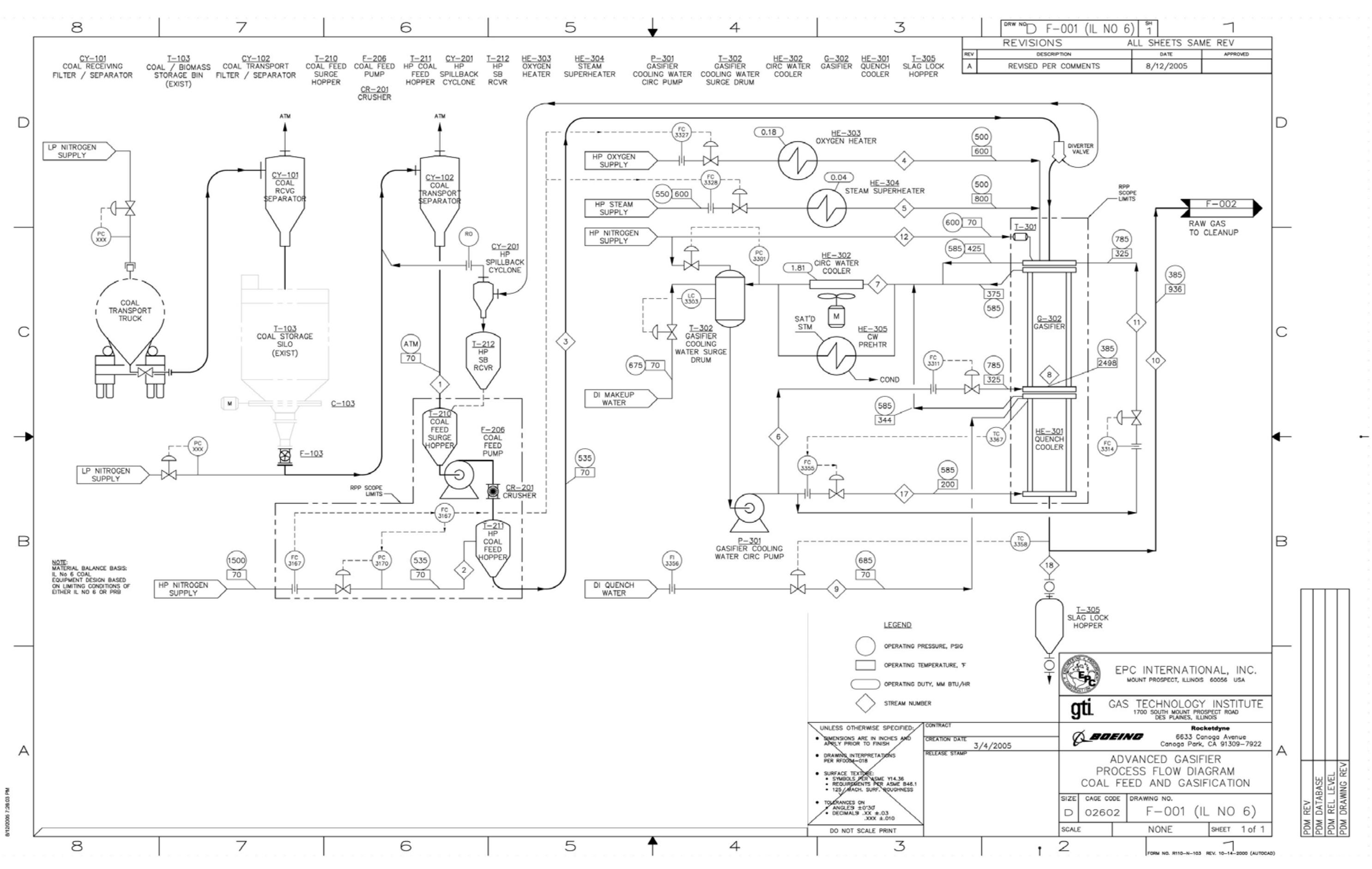




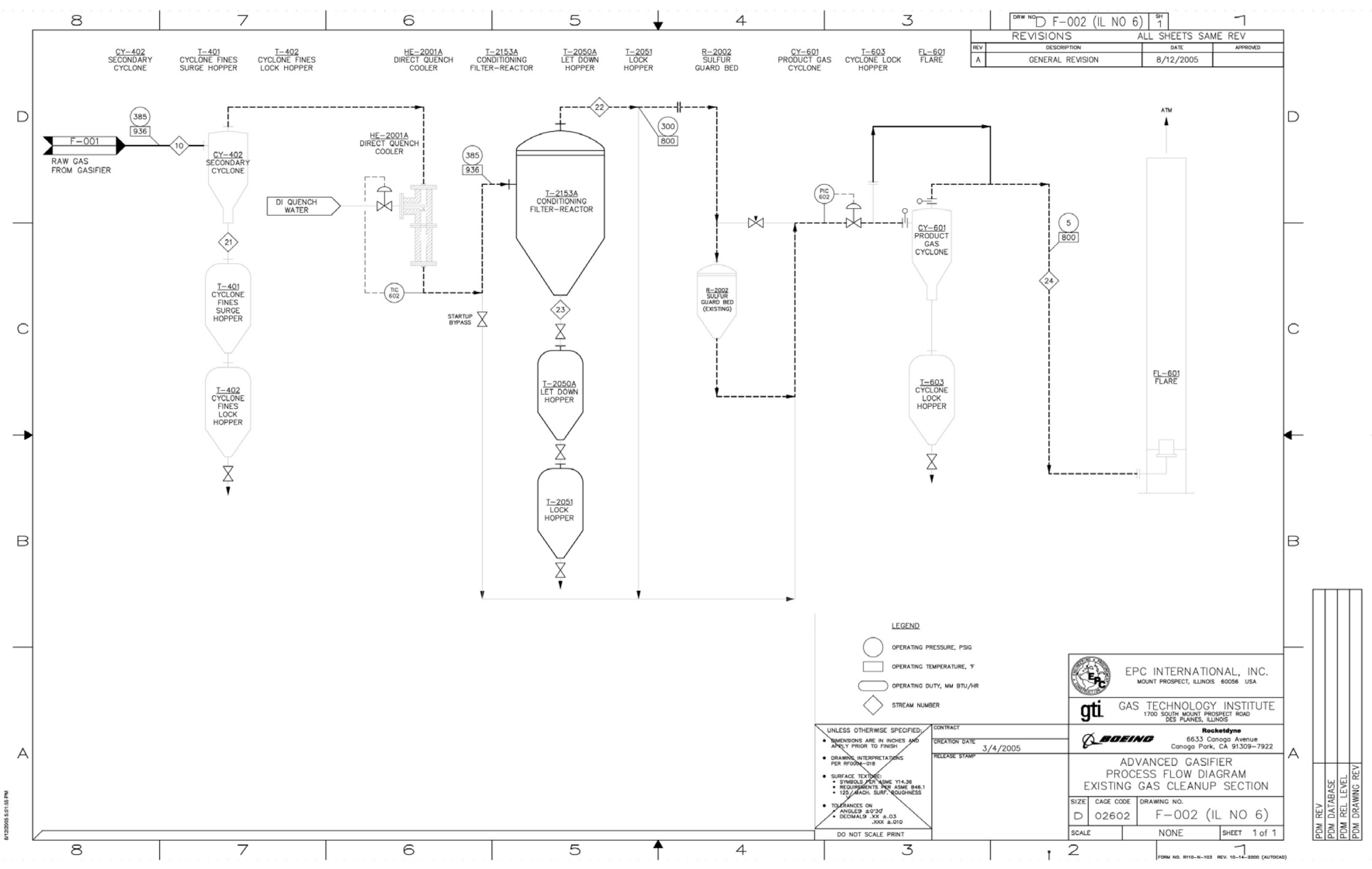


Table XI. Gasifier pilot plant stream data at battery limits for Illinois \#6 coal.

\begin{tabular}{|c|c|c|c|c|c|c|}
\hline Description & $\begin{array}{l}\text { Illinois \#6 } \\
\text { Coal }\end{array}$ & $\begin{array}{c}\text { N2 Transport } \\
\text { Gas }\end{array}$ & Oxygen & Steam & $\begin{array}{l}\text { Quench } \\
\text { Water }\end{array}$ & $\begin{array}{l}\text { Quenched } \\
\text { Syngas }\end{array}$ \\
\hline Temperature (C) & 21 & 21 & 191 & 566 & 21 & 538 \\
\hline Pressure (MPa) & 0.10 & 3.79 & 3.45 & 3.45 & 4.83 & 2.76 \\
\hline Gases \& Vapors, kg/hr & & 31.8 & 567.0 & 136.1 & & 1660.0 \\
\hline $\mathrm{CO}$ & & & & & & 1045.69 \\
\hline $\mathrm{CO}_{2}$ & & & & & & 107.94 \\
\hline $\mathrm{H}_{2}$ & & & & & & 40.57 \\
\hline $\mathrm{CH}_{4}$ & & & & & & 0.18 \\
\hline $\mathrm{O}_{2}$ & & & 561.33 & & & 0.00 \\
\hline $\mathrm{N}_{2}$ & & 31.8 & 5.67 & & & 46.66 \\
\hline $\mathrm{H}_{2} \mathrm{~S}$ & & & & & & 18.16 \\
\hline $\mathrm{COS}$ & & & & & & 2.80 \\
\hline $\mathrm{NH}_{3}$ & & & & & & 0.03 \\
\hline $\mathrm{HCN}$ & & & & & & 0.02 \\
\hline $\mathrm{HCl}$ & & & & & & 2.26 \\
\hline $\mathrm{H}_{2} \mathrm{O}$ & & & & 136.1 & & 395.67 \\
\hline Total Dry & & 31.8 & 567.0 & & & 1264.32 \\
\hline Total Wet & & 31.8 & 567.0 & 136.1 & & 1659.98 \\
\hline Gas Density, kg/m³ & & 43.4 & 28.4 & 9.1 & & 8.0 \\
\hline $\mathrm{MW}, \mathrm{kg} / \mathrm{kg}$ mole & & 28.01 & 31.95 & 18.02 & & 19.72 \\
\hline $\mathrm{HHV}$, gas $(\mathrm{MJ} / \mathrm{kg})$ & & & & & & 11.1 \\
\hline & & & & & & \\
\hline Solids/Liquids (kg/hr) & 680.4 & & & & 317.5 & 72.8 \\
\hline Carbon & 478.3 & & & & & \\
\hline Hydrogen & 33.7 & & & & & \\
\hline Oxygen & 51.7 & & & & & \\
\hline Nitrogen & 9.4 & & & & & \\
\hline Sulfur & 18.8 & & & & & \\
\hline Chlorine & 2.2 & & & & & \\
\hline Ash/Slag & 72.7 & & & & & 72.8 \\
\hline Water & 13.6 & & & & 317.5 & \\
\hline Total Dry & 666.8 & & & & & 72.8 \\
\hline Total Wet & 680.4 & & & & 317.5 & 72.8 \\
\hline HHV, Solids (MJ/kg) & 29.9 & & & & & \\
\hline
\end{tabular}


Table XII. Gasifier pilot plant stream data at battery limits for Powder River Basin coal.

\begin{tabular}{|c|c|c|c|c|c|c|}
\hline Description & PRB Coal & $\begin{array}{c}\mathbf{N 2} \\
\text { Transport } \\
\text { Gas }\end{array}$ & Oxygen & Steam & $\begin{array}{l}\text { Quench } \\
\text { Water }\end{array}$ & $\begin{array}{c}\text { Quenched } \\
\text { Syngas }\end{array}$ \\
\hline Temperature (C) & 21 & 21 & 191 & 566 & 21 & 538 \\
\hline Pressure (MPa) & 0.10 & 3.79 & 3.45 & 3.45 & 4.83 & 2.76 \\
\hline Gases \& Vapors, kg/hr & & 31.8 & 519.4 & 0.0 & & 1452.9 \\
\hline $\mathrm{CO}$ & & & & & & 917.97 \\
\hline $\mathrm{CO}_{2}$ & & & & & & 0.00 \\
\hline $\mathrm{H}_{2}$ & & & & & & 17.79 \\
\hline $\mathrm{CH}_{4}$ & & & & & & 0.02 \\
\hline $\mathrm{O}_{2}$ & & & 514.1783 & & & 0.00 \\
\hline $\mathrm{N}_{2}$ & & 31.8 & 5.19372 & & & 41.77 \\
\hline $\mathrm{H}_{2} \mathrm{~S}$ & & & & & & 0.00 \\
\hline $\mathrm{COS}$ & & & & & & 6.75 \\
\hline $\mathrm{NH}_{3}$ & & & & & & 0.00 \\
\hline $\mathrm{HCN}$ & & & & & & 2.06 \\
\hline $\mathrm{HCl}$ & & & & & & 0.18 \\
\hline $\mathrm{H}_{2} \mathrm{O}$ & & & & 0.0 & & 466.42 \\
\hline Total Dry & & 31.8 & 519.4 & & & 986.53 \\
\hline Total Wet & & 31.8 & 519.4 & 0.0 & & 1452.95 \\
\hline Gas Density, $\mathrm{kg} / \mathrm{m}^{3}$ & & 43.4 & 28.4 & & & 8.8 \\
\hline $\mathrm{MW}, \mathrm{kg} / \mathrm{kg}$ mole & & 28.01 & 31.95 & 18.02 & & 19.72 \\
\hline $\mathrm{HHV}$, gas $(\mathrm{MJ} / \mathrm{kg})$ & & & & & & 9.0 \\
\hline Solids/Liquids (kg/hr) & 680.4 & & & & 317.5 & 50.7 \\
\hline Carbon & 395.7 & & & & & \\
\hline Hydrogen & 28.2 & & & & & \\
\hline Oxygen & 93.9 & & & & & \\
\hline Nitrogen & 5.9 & & & & & \\
\hline Sulfur & 3.7 & & & & & \\
\hline Chlorine & 0.2 & & & & & \\
\hline Ash/Slag & 50.7 & & & & & 50.7 \\
\hline Water & 102.1 & & & & 317.5 & \\
\hline Total Dry & 578.3 & & & & & 50.7 \\
\hline Total Wet & 680.4 & & & & 317.5 & 50.7 \\
\hline HHV, Solids (MJ/kg) & 29.9 & & & & & \\
\hline
\end{tabular}




\section{Figure 18. Pilot Plant Concept Elevation.}

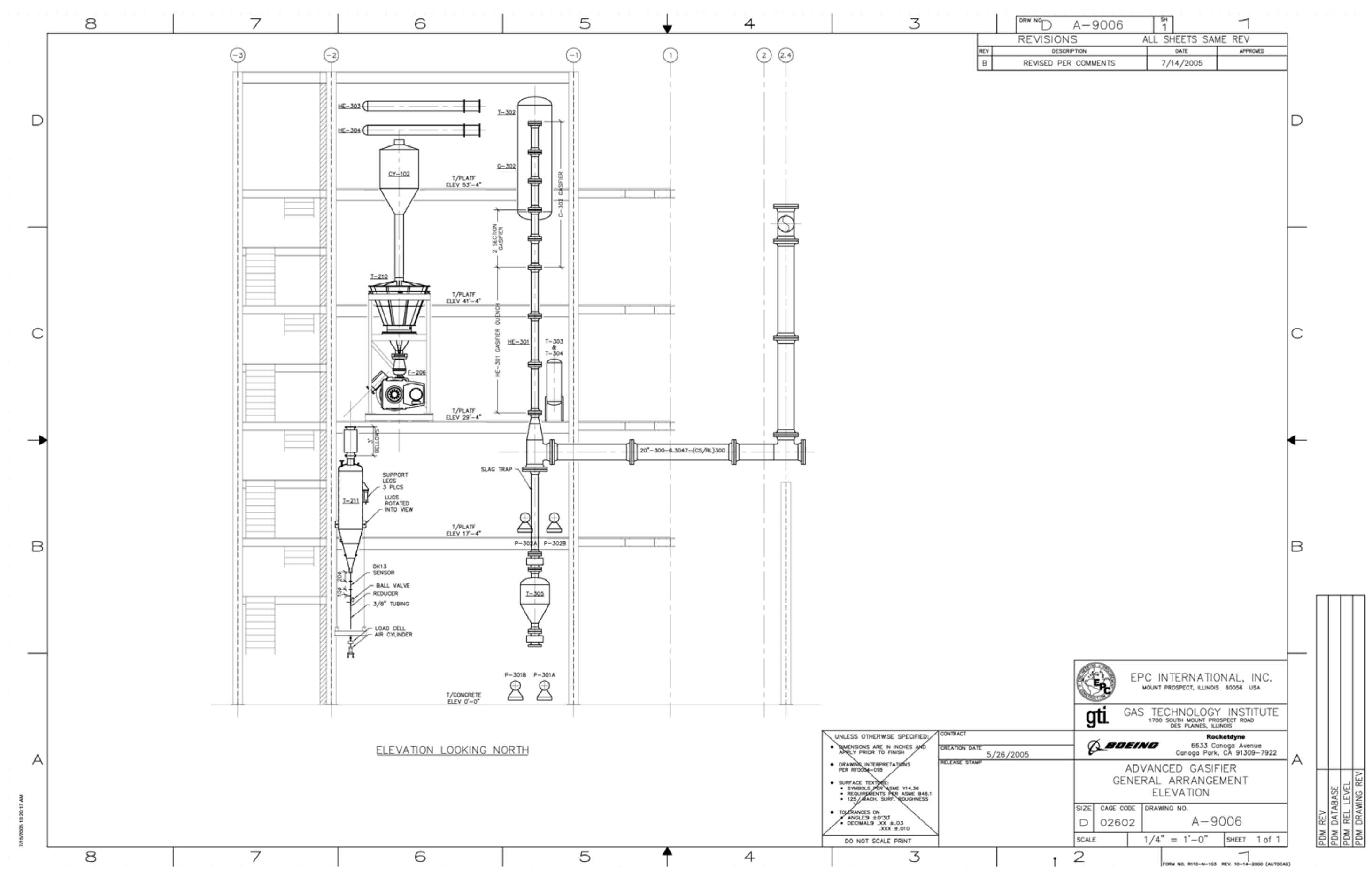

Figure 19. Pilot Plant Concept Plot Plan. 


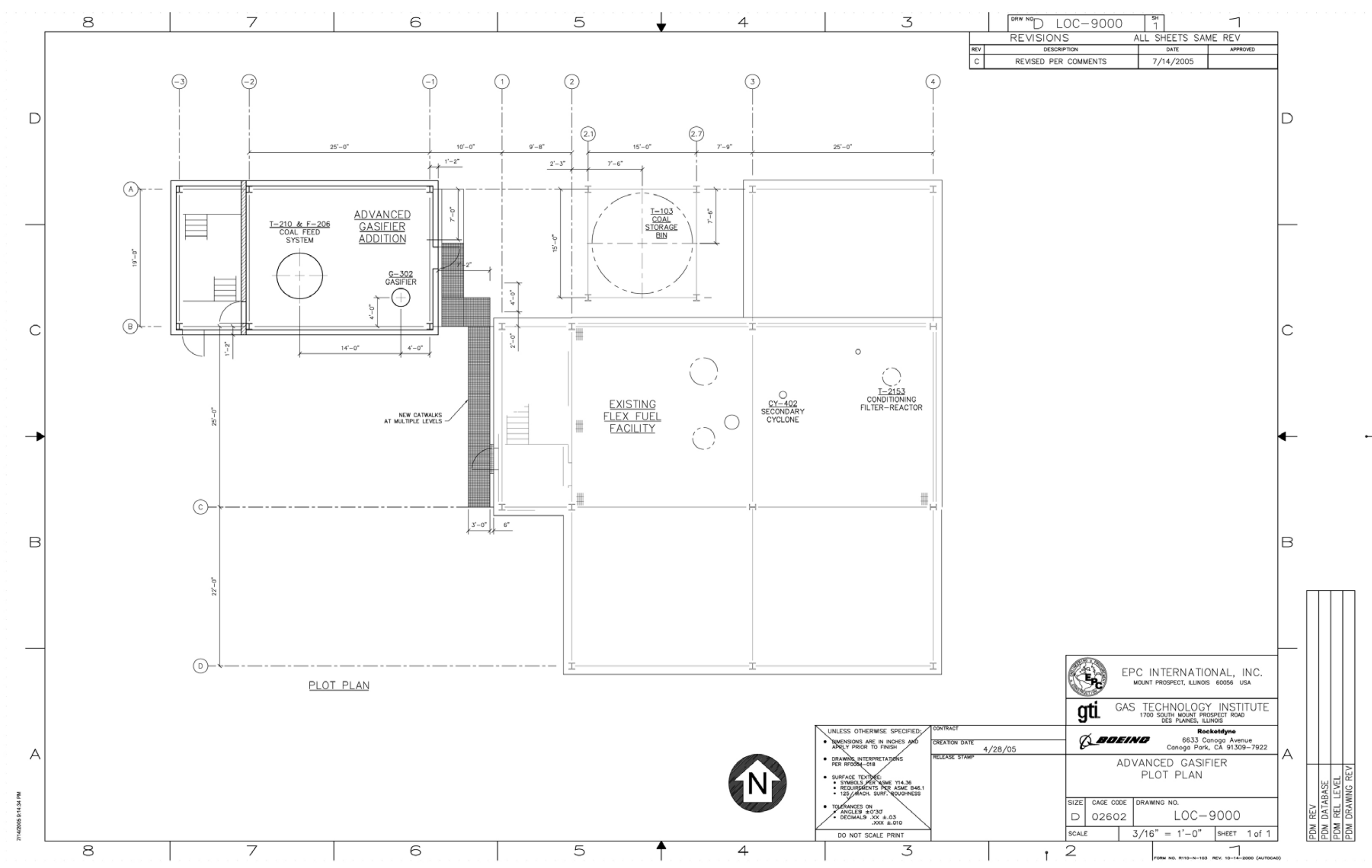




\section{FLUENT Modeling}

In the current effort the FLUENT CFD code was used to conduct coal gasification modeling of an entrained flow gasifier. The goal of this task was to determine the optimum settings for the discrete phase model parameters used within FLUENT and run CFD cases with these settings using the available equilibrium and finite rate combustion models. The parameters tested in these cases were: (i) the number of stochastic tracking tries, (ii) the number of discrete phase tracking steps, (iii) the number of gas phase iterations per discrete phase iteration. An optimum combination of these parameters was identified that minimized convergence time while maintaining acceptable accuracy.

In addition to these parameters, the best method for injecting the coal particles was also explored. The group and surface injection settings were two main options readily available within FLUENT that were initially evaluated. An alternative particle injection technique which required the creation of a user-defined input file was also evaluated.

One and two PDF equilibrium combustion models were used, as well as a finite rate combustion model. Two gasifier geometries were also considered. Due to the shorter run time required for the single mixture fraction PDF cases; this model was used for doing the main evaluation of the optimum parameter settings.

Using the single PDF approach, the DPM parameters were first optimized using a simplified plug flow model gasifier geometry, and then additional cases were run using a more realistic geometry that represented a single injection stream tube representing approximately one of the 36 injection elements in the full-size gasifier design. All of the cases were modeled using an assumption of a two-dimensional axisymmetric geometry.

In addition to the portions of this task discussed above, a separate effort by FLUENT personnel to take an alternative modeling approach was made. For this portion of the task, the single stream tube geometry was used along with the selected finite rate combustion mechanism. The goal of this effort was to create and utilize user defined functions within FLUENT in order to improve the current models used for the discrete phase.

Pilot plant gasifier modeling was performed using the updated FLUENT code, generating temperature and velocity profiles as well as syngas composition at the gasifier exit (before quenching) corresponding to the inlet conditions given in Table XI for the pilot plant gasifier with Illinois \#6 coal. Results are shown in Figures 20-22. Evaluation of fluid pathlines and stream function results from this analysis indicate that the size and temperature of the recirculation zone is adequate to sustain the reaction at steady-state operation. Figure 20 illustrates how rapid changes in gasifier product gas temperature occurs at the head end of the gasifier, consistent with the rapid mixing and particle heat-up expected with the PWR rapid-mix injector. Figure 21 shows a close-up view of the temperature profile in the gasifier head-end. Figure 22 shows contours of gas phase velocity magnitude for the same injector head-end zone shown in Figure 21.

Species mass fractions predicted by the updated FLUENT model for the major constituents at the pilot plant gasifier exit (not including $\mathrm{N}_{2}, \mathrm{H}_{2} \mathrm{~S}, \mathrm{NH}_{3}$, or trace constituents) are as follows:

$\begin{array}{ll}\mathrm{CO}: & 0.7438 \\ \mathrm{H}_{2}: & 0.0311 \\ \mathrm{CO}_{2}: & 0.1123 \\ \mathrm{H}_{2} \mathrm{O}: & 0.066\end{array}$




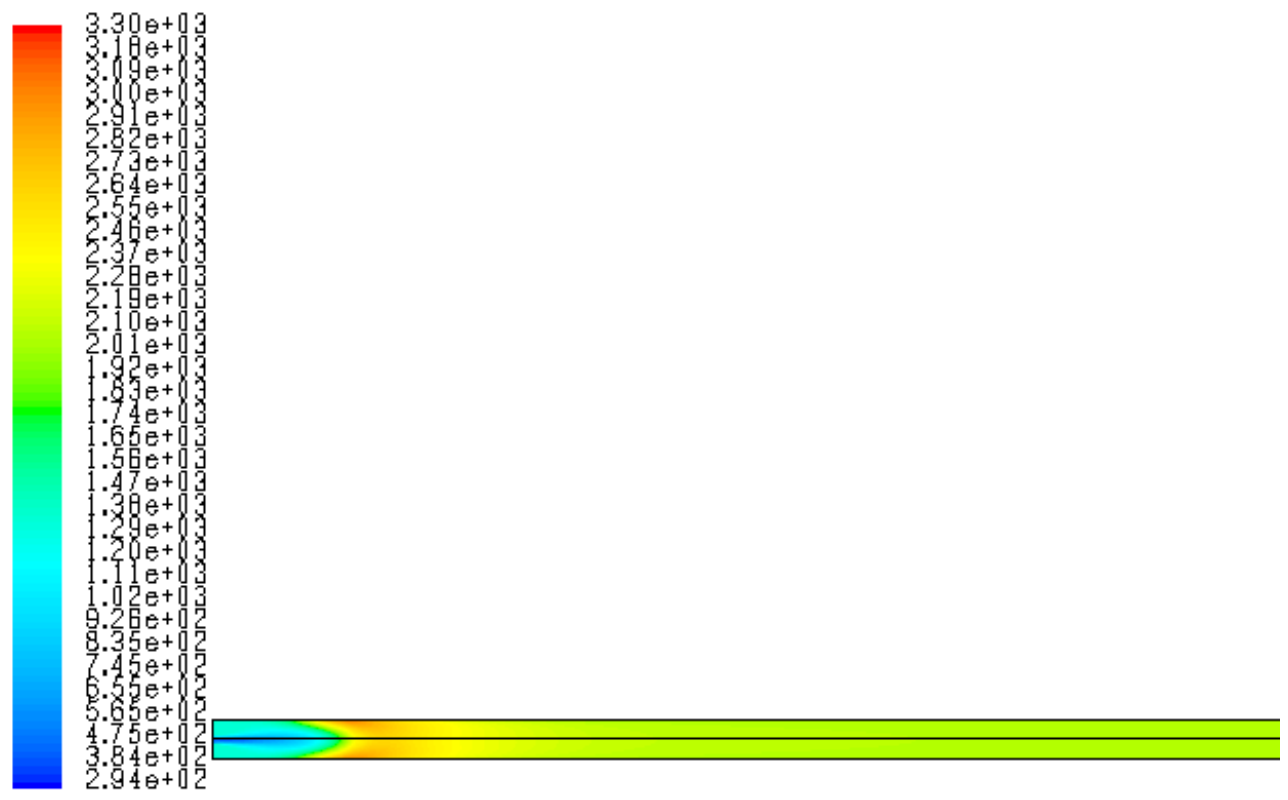

Contours of Statio Temperature (k)

Figure 20. Contours of static temperature (K).

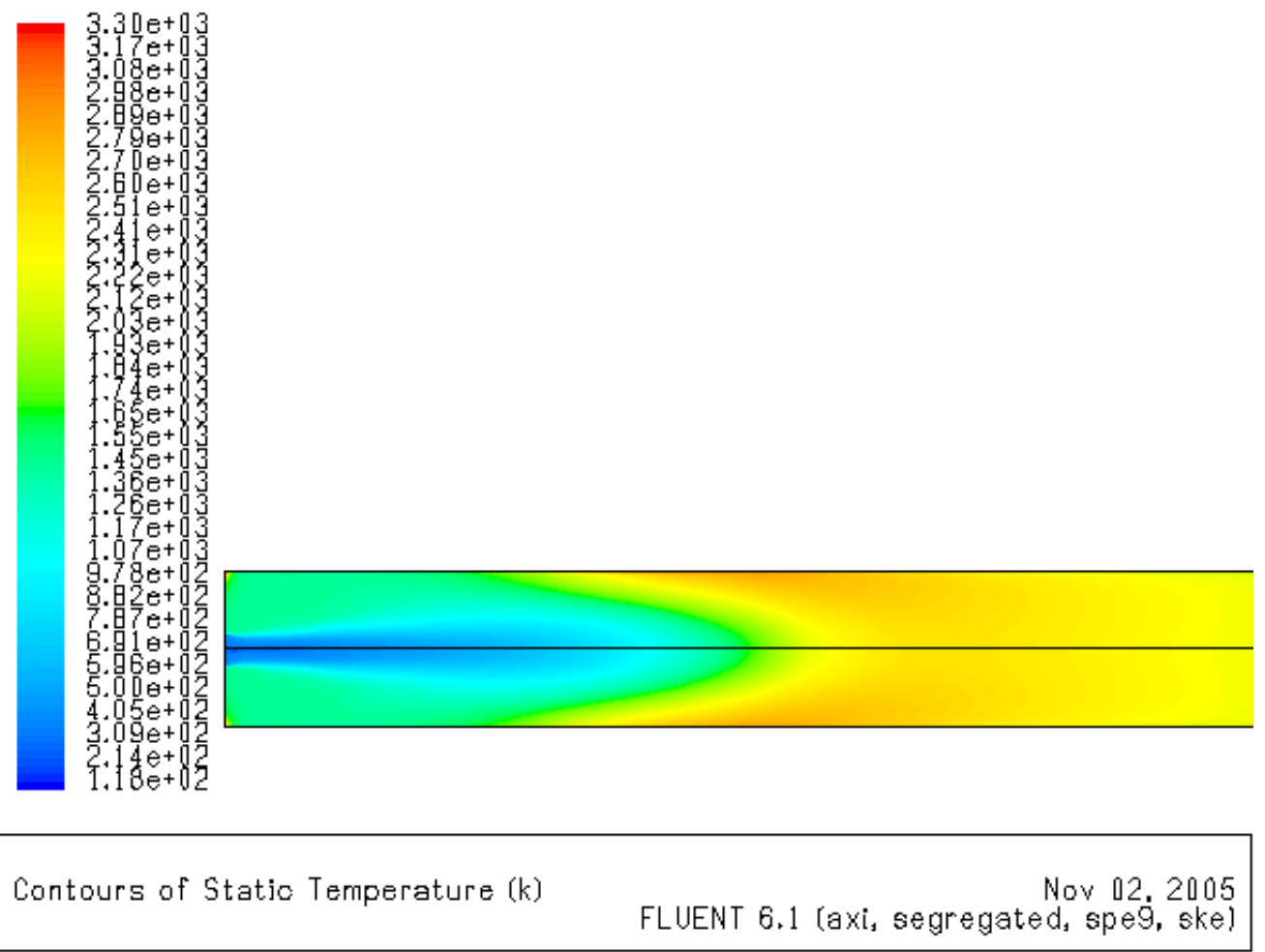

Figure 21. Injector-end contours of static temperature (K). 


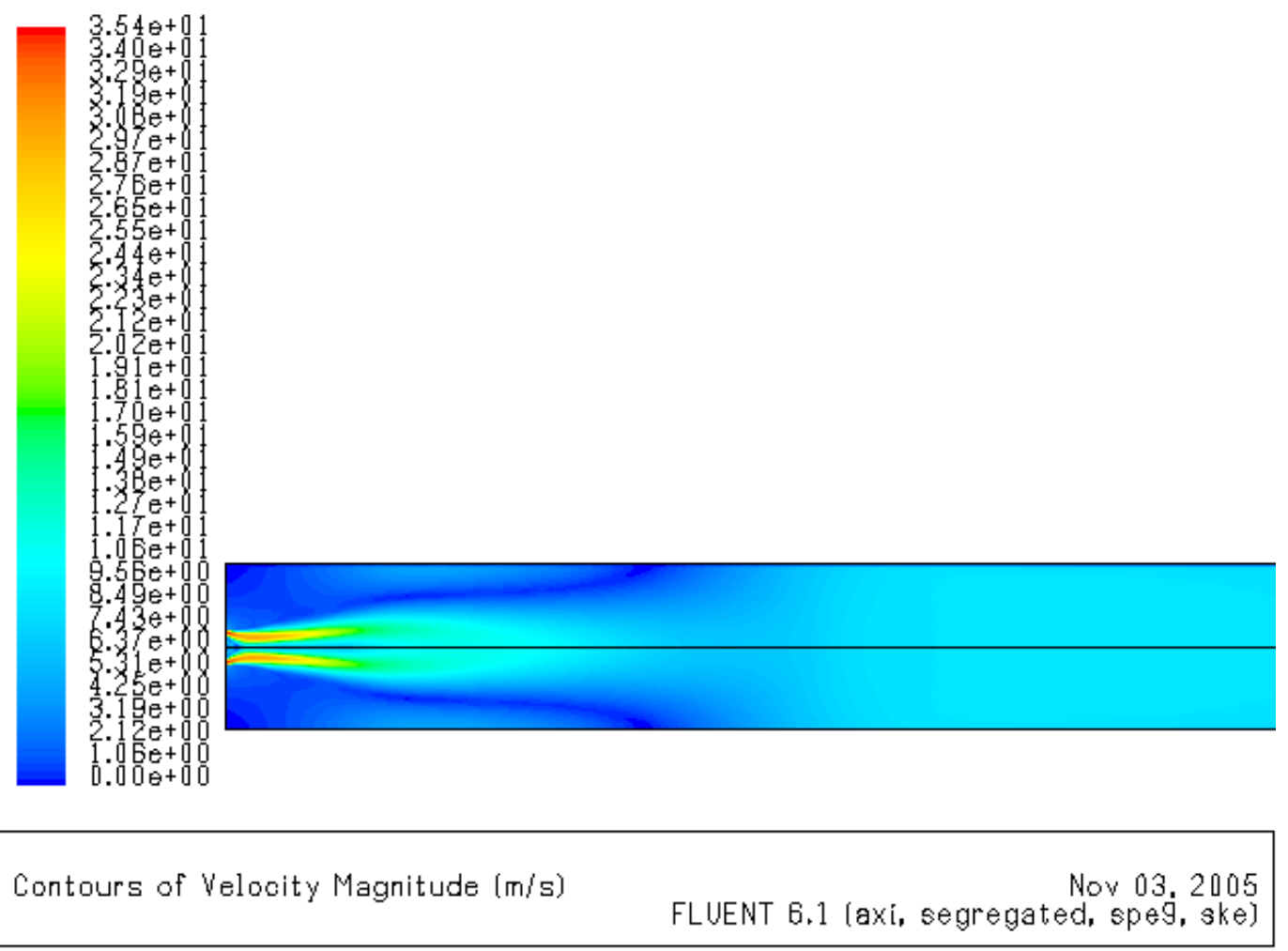

Figure 22. Injector-end contours of velocity magnitude $(\mathrm{m} / \mathrm{s})$.

\section{Pilot Plant Project Schedule}

The estimated schedule for the pilot plant project is shown in Figure 23. For purposes of estimating the schedule, a start date of April 1, 2004 was assumed. Schedule estimates for the gasifier and feed system, as well as balance of plant, reflect an assumption that the effort is not constrained by budgetary limitations. The test program reflects an assumed cumulative total hot fire test time of 1,000 hours, with 100 hours of testing during the pilot plant integration and check-out phase (WBS 51000) to establish operational procedures. The remaining hours are split among a bituminous and sub-bituminous coal (Coal \#1 in WBS 52000, Coal \#2 in WBS 53000) for long-duration testing. These tests would be conducted in a series of tests of 100 hours duration or more. 


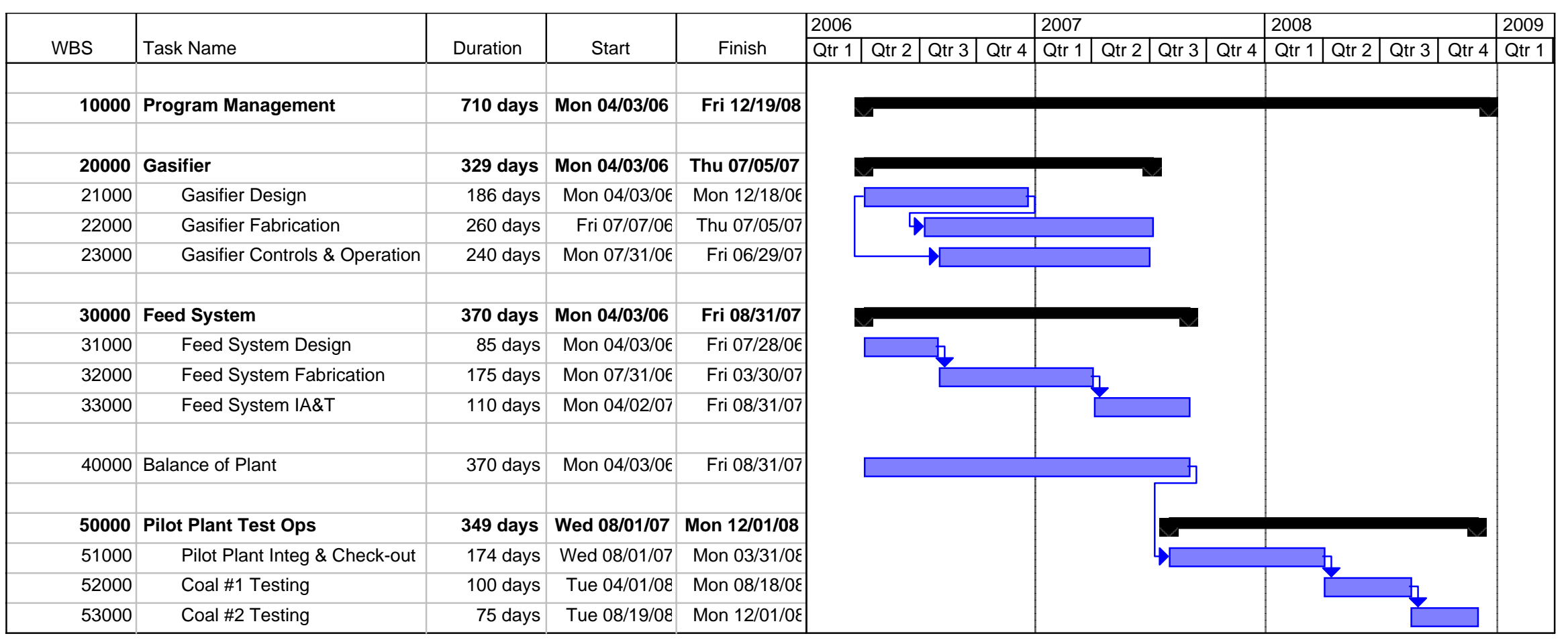

Figure 23. Estimated schedule for the pilot plant concept, including design, installation and long-duration testing. 


\section{Pilot Plant Cost Estimate}

The estimated cost of $\$ 25.6 \mathrm{M}$ for the pilot plant project defined in this report is summarized in Table XIII. Costs represent "then year" \$'s consistent with the technical content and schedule described previously. This cost estimate is "Rough Order of Magnitude", submitted for budgetary and planning purposes only.

Table XIII. Estimated cost for pilot plant concept design, installation, and long-duration testing.

\begin{tabular}{|c|c|c|c|c|}
\hline $\begin{array}{c}\text { Pilot Plant } \\
\text { Element }\end{array}$ & Material (1) & Labor (2) & Other Costs ${ }^{(3)}$ & Total Cost \\
\hline Gasifier & $\$ 1,432,000$ & $\$ 3,902,000$ & $\$ 872,000$ & $\$ 6,206,000$ \\
\hline Feed System & $\$ 1,393,000$ & $\$ 943,000$ & $\$ 451,000$ & $\$ 2,787,000$ \\
\hline $\begin{array}{c}\text { Balance of } \\
\text { Plant (4) }\end{array}$ & $\$ 6,901,000$ & $\$ 432,000$ & $\$ 1,323,000$ & $\$ 8,656,000$ \\
\hline $\begin{array}{c}\text { Long Duration } \\
\text { Testing }\end{array}$ & $\$ 5,311,000$ & $\$ 1,351,000$ & $\$ 1,316,000$ & $\$ 7,978,000$ \\
\hline Total Program & $\mathbf{\$ 1 5 , 0 3 7 , 0 0 0}$ & $\mathbf{\$ 6 , 6 2 8 , 0 0 0}$ & $\mathbf{\$ 3 , 9 6 2 , 0 0 0}$ & $\mathbf{\$ 2 5 , 6 2 7 , 0 0 0}$ \\
\hline
\end{tabular}

(1) Material includes all materials, such as test apparatus, raw stock, equipment, and subcontracts. A subcontract to Stamet for dry pump design, fabrication and test is included.

(2) Labor includes all PWR labor directly associated with a pilot plant element.

(3) Other costs include travel, reporting, program management, support personnel, and other costs not directly attributable to a specific pilot plant element.

(4) Balance of plant includes all site modifications at GTI

Gasifier material costs include materials for gasifier chamber fabrication and CMC liner procurement, as well as cost for external machine shops to perform rough machining of gasifier chamber hardware.

Gasifier labor costs use PWR labor for the design and in-house fabrication/assembly of the gasifier, as well as engineering analysis for gasifier control and operations.

Feed System material costs include support by Stamet, Inc. $(\$ 1.26 \mathrm{M})$ for feed system design, procurement, and test support. It also includes $\$ 0.14 \mathrm{M}$ for PWR's feed system hardware, such as the high pressure hopper, pressure regulator, valves, and instrumentation, and bellows. Feed System labor baselines PWR labor for feed system design, procurement, and closed-loop feed system testing.

Balance of Plant material costs are based on estimates from Gas Technology Institute (\$6.9M) for the design, fabrication and construction of the balance of plant facilities, as well as initial closed loop testing of the feed system. Balance of Plant labor costs reflect estimated PWR labor for technical coordination with GTI during the design and build phase.

Long Duration Testing material costs are based on estimates from GTI $(\$ 5.3 \mathrm{M})$ for gasifier integration and initial check-out testing, as well as long duration testing on Illinois \#6 and Powder River Basin coals. This reflects 1,000 hours cumulative hot-fire testing at GTI. Long Duration Testing include PWR test support on-site at GTI as well as analysis and engineering support from PWR facilities in Canoga Park. This will include evaluation of CFD model predictions relative to experimental results. 


\section{Conclusion}

A pilot plant concept has been defined that incorporates the preferred commercial gasifier configuration. The concept is based on preliminary definition of pilot plant gasifier, feed system and balance of plant design approaches. The pilot plant concept design approach is scalable and traceable to the commercial gasifier configuration. An updated FLUENT model has been developed, with model results indicating stable steady-state operation of the pilot plant gasifier. Based on the technical definition of the pilot plant concept, the schedule and cost for design, installation and long-duration test operation of the pilot plant were estimated at 33 months and $\$ 25.6 \mathrm{M}$. 


\section{GRAPHICAL MATERIALS LISTS}

\section{LIST OF FIGURES}

FIGURE 1. GASIFIER CONFIGURATION TRADE TREE FOR COMMERCIAL CONCEPT DEFINITION. .......................... 8

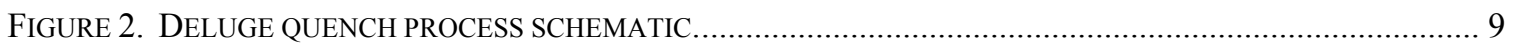

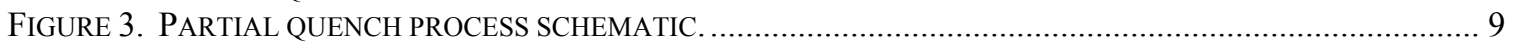

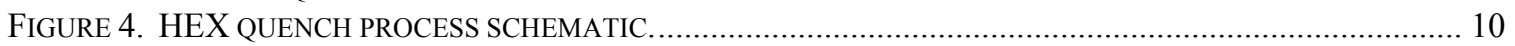

FIGURE 5. BLOCK DIAGRAM FOR REFERENCE IGCC PLANT CONFIGURATION............................................. 17

FIGURE 6. BLOCK DIAGRAM FOR IGCC PLANT WITH PWR ADVANCED GASIFIER. SYSTEM WITH HEX QUENCH HAS HEAT EXCHANGER IN PLACE OF QUENCH RING, AND WILL PROVIDE HIGH PRESSURE STEAM

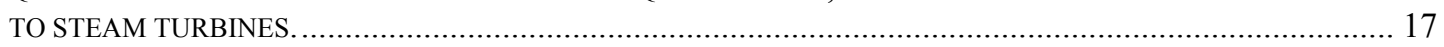

FigURE 7. PLAN AND ELEVATION FOR A 113,400 KG/HR (3,000 TPD) PWR ADVANCED GASIFIER, INCLUDING HEX QUENCH AND SLAG/FLY ASH REMOVAL. FOOTPRINT IS 18.3 M BY 9.1 M (60 FT BY 30 FT), WITH AN ELEVATION OF 23.6 M (77.5 FT), AND <21.3 M (<70 FT) WITHOUT THE HEX..................................... 19

FIGURE 8. BLOCK DIAGRAM FOR REFERENCE HYDROGEN PLANT CONFIGURATION..................................... 22

FIGURE 9. BLOCK DIAGRAM FOR PWR ADVANCED GASIFIER HYDROGEN PLANT CONFIGURATION................ 22

FIGURE 10. HYDROGEN SALES PRICE VERSUS FUEL COST FOR THE REFERENCE PLANT AND PWR ADVANCED GASIFIER, WITH SEQUESTRATION-READY $\mathrm{CO}_{2}$ SOLD FOR \$11/METRIC TON AT THE PLANT GATE. ........... 25

FIGURE 11. HYDROGEN SALES PRICE VERSUS FUEL COST FOR THE REFERENCE PLANT AND PWR ADVANCED GASIFIER, WITH SEQUESTRATION-READY $\mathrm{CO}_{2}$ DELIVERED AT THE PLANT GATE. .................................. 25

FIGURE 12. HYDROGEN SALES PRICE VERSUS FUEL COST FOR THE REFERENCE PLANT AND PWR ADVANCED

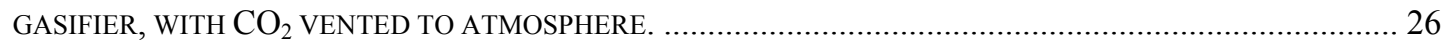

FigURE 13. WORK BREAKDOWN STRUCTURE (WBS) FOR THE GASIFIER PILOT PLANT COST ESTIMATE. ....... 31

FIGURE 14. BLOCK FLOW DIAGRAM FOR THE PILOT PLANT GASIFIER SYSTEM CONCEPT. ................................ 33

FigURE 15. CONCEPTUAL DRAWING OF THE PILOT PLANT GASIFIER AND QUENCH SECTIONS. APPROXIMATE

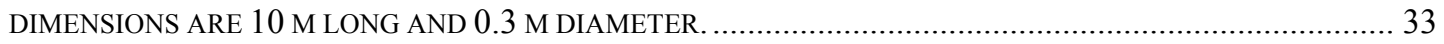

FIGURE 16. PROCESS FLOW DIAGRAM FOR THE ADVANCED GASIFIER SYSTEM PILOT PLANT -FEED SYSTEM

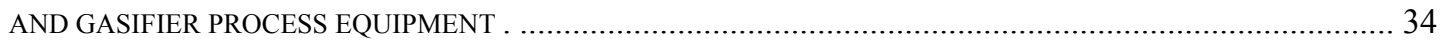

FIGURE 17. PROCESS FLOW DIAGRAM FOR THE ADVANCED GASIFIER SYSTEM PILOT PLANT - SYNGAS CLEAN-

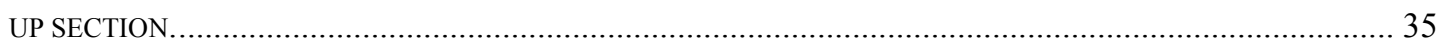

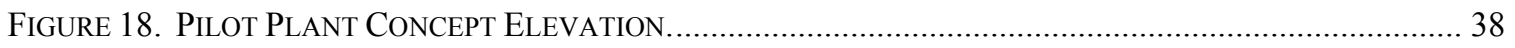

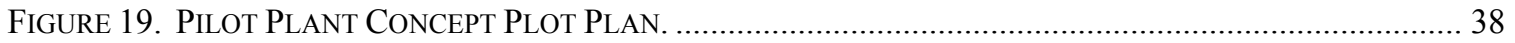

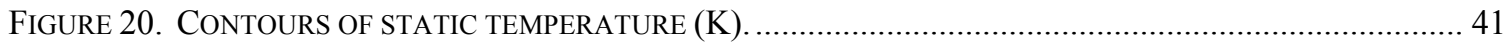

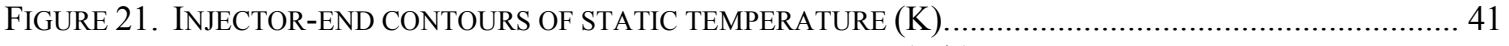

FIGURE 22. INJECTOR-END CONTOURS OF VELOCITY MAGNITUDE (M/S) .................................................... 42

FIGURE 23. ESTIMATED SCHEDULE FOR THE PILOT PLANT CONCEPT, INCLUDING DESIGN, INSTALLATION AND

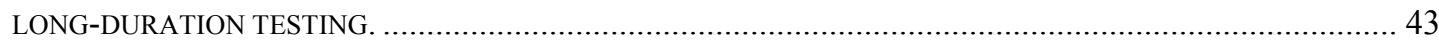




\section{LIST OF TABLES}

Table I. Groundrules And Assumptions Common to IGCC And H Hroduction Cases. ................ 12

TABle II. IGCC Power Production CASE Specific Groundrules And ASSumptions. ....................... 13

Table III. Hydrogen Production Case SPecific Groundrules And Assumptions. ......................... 14

TABLE IV. IGCC PERFORMANCE EVALUATION FOR REFERENCE CASE WITH TEXACO GASIFIER AND VARIOUS PWR ADVANCED GASIFIER SYSTEM CONFIGURATIONS.......................................................... 18

TABLE V. AVAILABILITY, CAPITAL COST, EFFICIENCY AND COST OF ELECTRICITY ESTIMATES FOR POTENTIAL

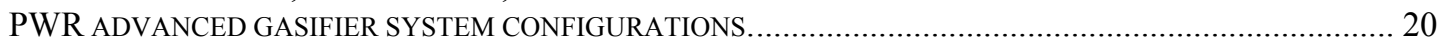

TABLE VI. "BEST” PWR GASIFIER SYSTEM CONFIGURATIONS, PLANT ATTRIBUTES, AND COE BENEFIT RELATIVE TO REFERENCE PLANT. THE “DRY PUMP + CMC INSERT + PARTIAL QUENCH” CONFIGURATION WAS SELECTED AS THE PREFERRED CONFIGURATION FOR NEAR TERM COMMERCIALIZATION.

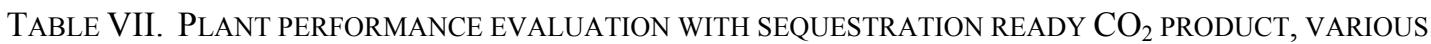

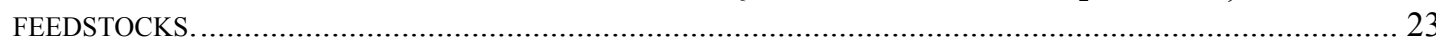

TABle VIII. Plant PERFormance EVALUATION WITH $\mathrm{CO}_{2}$ VENTED tO ATMOSPHERE, VARIOUS FEEDSTOCKS.

TABLE IX. SUMMARY OF PLANT-LEVEL BENEFITS OF PWR ADVANCED GASIFIER TECHNOLOGY RELATIVE TO A TEXACO QUENCH GASIFIER FOR POWER AND HYDROGEN PRODUCTION.

TABLE X. THE PILOT PLANT GASIFIER CONCEPT REQUIREMENTS WERE SELECTED TO BEST REFLECT THE

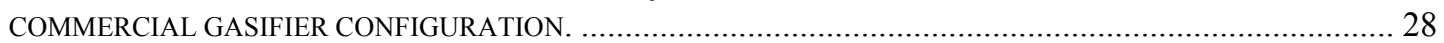

TABLE XI. GASIFIER PILOT PLANT STREAM DATA AT BATTERY LIMITS FOR ILLINOIS \#6 COAL. ................... 36

TABLE XII. GASIFIER PILOT PLANT STREAM DATA AT BATTERY LIMITS FOR POWDER RIVER BASIN COAL... 37

TABLE XIII. ESTIMATED COST FOR PILOT PLANT CONCEPT DESIGN, INSTALLATION, AND LONG-DURATION TESTING 


\section{REFERENCES}

1. "Quality Guidelines for Energy System Studies", February 24, 2004, prepared by Office of Systems and Policy Support. G. V. McGurl et al.

2. “Texaco Gasifier IGCC Base Cases", PED-IGCC-98-001, Revised June 2000, Process Engineering Division, NETL.

3. "Tampa Electric Polk Power Station Integrated Gasification Combined Cycle Project: Final Technical Report", August 2002.

4. "Wabash River Coal Gasification Repowering Project: Final Technical Report", August 2000.

5. "Advanced Fossil Power Systems Comparison Study: Final Report", December, 2002, E. L. Parsons et al.

6. "Co-production of Hydrogen, Electricity and $\mathrm{CO} 2$ from Coal with Commercially Ready Technology - Part B: Economic Analysis”, T. Kreutz et al., Int. J. Hydrogen Energy, 2004. 


\section{LIST OF ACRONYMS AND ABBREVIATIONS}

\begin{tabular}{|c|c|}
\hline AGSD & Advanced Gasification Systems Development \\
\hline ASU & Air Separation Unit \\
\hline BFW & Boiler Feed Water \\
\hline BOM & Bill Of Material \\
\hline${ }^{\circ} \mathrm{C}$ & Degrees Celsius \\
\hline CFD & Computational Fluid Dynamics \\
\hline CGE & Cold Gas Efficiency \\
\hline $\mathrm{CMC}$ & Ceramic Matrix Composite \\
\hline $\mathrm{CO}$ & Carbon Monoxide \\
\hline $\mathrm{CO}_{2}$ & Carbon Dioxide \\
\hline $\mathrm{COE}$ & Cost Of Electricity \\
\hline CY & Calendar Year \\
\hline DOE & Department Of Energy \\
\hline DPM & Discrete Phase Model \\
\hline EOR & Enhanced Oil Recovery \\
\hline${ }^{\circ} \mathrm{F}$ & Degrees Fahrenheit \\
\hline FFTF & Flex-Fuel Test Facility \\
\hline $\mathrm{ft}$ & foot \\
\hline GJ & Gigajoule \\
\hline GOX & Gaseous oxygen \\
\hline GT & Gas turbine \\
\hline GTI & Gas Technology Institute \\
\hline $\mathrm{H}_{2}$ & Hydrogen \\
\hline $\mathrm{H}_{2} \mathrm{O}$ & Water \\
\hline $\mathrm{H}_{2} \mathrm{~S}$ & Hydrogen Sulfide \\
\hline HEX & Heat Exchanger \\
\hline $\mathrm{HHV}$ & Higher Heating Value \\
\hline $\mathrm{HP}$ & High pressure \\
\hline $\mathrm{hr}$ & hour \\
\hline HRSG & Heat recovery steam generator \\
\hline IA\&T & Integration, assembly and test \\
\hline IGCC & Integrated Gasification Combined Cycle \\
\hline IP & Intermediate Pressure \\
\hline $\mathrm{kg}$ & kilogram \\
\hline $\mathrm{kW}$ & kilowatt \\
\hline $\mathrm{kWe}$ & kilowatt electric \\
\hline kWth & kilowatt thermal \\
\hline $1 b_{m}$ & pound, mass \\
\hline LP & Low pressure \\
\hline $\mathrm{m}$ & Meter \\
\hline MDEA & Methyldiethanolamine \\
\hline MJ & Megajoule \\
\hline MMBtu & Million British Thermal Units \\
\hline $\mathrm{MPa}$ & Megapascal \\
\hline MSCF & Thousand standard cubic feet \\
\hline MTTR & Mean Time To Repair \\
\hline MW & Megawatt \\
\hline $\mathrm{N}_{2}$ & Nitrogen \\
\hline NACE & National Association of Corrosion Engineers \\
\hline NETL & National Energy Technology Laboratory \\
\hline $\mathrm{NH}_{3}$ & Ammonia \\
\hline
\end{tabular}




\begin{tabular}{|l|l|}
\hline $\mathrm{Nm}^{3}$ & Normal (standard) cubic meter \\
\hline $\mathrm{O}_{2}$ & Oxygen \\
\hline P\&ID & Piping and Instrumentation Diagram \\
\hline PDF & Probability Density Function \\
\hline PFD & Process Flow Diagram \\
\hline PRB & Powder River Basin \\
\hline PSA & Pressure Swing Absorption \\
\hline psia & Pounds (force) per square inch, absolute \\
\hline PWR & Pratt \& Whitney Rocketdyne, Inc. \\
\hline R & Rankine \\
\hline ROM & Rough Order of Magnitude \\
\hline S & Sulfur \\
\hline scf & Standard cubic foot \\
\hline SCOT & Shell Claus Off-Gas Treating \\
\hline sec & Second \\
\hline SMR & Steam Methane Reformer \\
\hline SRU & Sulfur Recovery Unit \\
\hline TPD & Tons Per Day \\
\hline$\Delta T$ & Temperature differential \\
\hline WBS & Work Breakdown Structure \\
\hline WGS & Water Gas Shift \\
\hline
\end{tabular}

